\title{
The Influence of the International Covenant on Economic, Social and Cultural Rights in Africa
}

\author{
Manisuli Ssenyonjo ${ }^{1}$
}

Published online: 25 July 2017

(C) The Author(s) 2017. This article is an open access publication

\begin{abstract}
Half a century ago, the United Nations General Assembly unanimously adopted two great covenants, the International Covenant on Civil and Political Rights (ICCPR) and the International Covenant on Economic, Social and Cultural Rights (ICESCR), which brought force of law to the rights declared in the Universal Declaration of Human Rights. Both covenants have been widely ratified by the vast majority of African States. However, a largely neglected area of study has been assessing the influence of the ICESCR in various parts of the world including Africa. This article assesses the influence of the ICESCR in Africa. It seeks to show how the ICESCR, as interpreted by the United Nations Committee on Economic, Social and Cultural Rights (CESCR) has, through the 50 years since its adoption, had influence on the regional and domestic protection of economic, social and cultural rights (ESC rights) in Africa. The article begins by considering the influence of the Covenant on the regional protection of human rights in Africa. This is followed by an analysis of the influence of the Covenant on the protection of ESC rights in domestic legal systems in Africa focusing primarily on the constitutional protection of ESC rights. It then considers the limited influence of the Covenant on national courts' jurisprudence in African States applying dualist and monist approaches to international treaties. It ends by making recommendations to maximize the influence of the ICESCR in the future.
\end{abstract}

Unless indicated otherwise, all internet material referred to in this article was last accessed on 13 February 2017.

Manisuli Ssenyonjo

manisuli.ssenyonjo@brunel.ac.uk

1 Professor of International Law and Human Rights, Brunel University, London, UK 
Keywords International Covenant on Economic, Social and Cultural

Rights · ICESCR · Africa · Dualism · Monism · Influence of international human rights treaties

\section{Introduction}

16 December 2016 marked 50 years since the United Nations (UN) General Assembly adopted in 1966 the International Covenant on Economic, Social and Cultural Rights ${ }^{1}$ (ICESCR or Covenant), the most comprehensive international treaty protecting economic, social and cultural (ESC) rights. Despite the wide ratification of the ICESCR by the vast majority (90\%) of African States, ${ }^{2}$ there are no studies evaluating the 'influence' (effect) of the Covenant in Africa. As of November 2016, with the exception of only six States (Botswana, Comoros, Mozambique, Sahrawi Arab Democratic Republic, São Tomé and Príncipe, and South Sudan), all other African States were parties to the ICESCR. Out of these, only eight African States-Algeria, Egypt, Guinea, Kenya, Libya, Madagascar, South Africa and Zambia-had entered some reservations or made declarations to the ICESCR, in particular to Article 13(2)(a) relating to the provision of 'compulsory and free' primary education. ${ }^{3}$ It should be noted that by the time the ICESCR entered into force on 3 January 1976, only seven African States had ratified the Covenant. ${ }^{4}$ Eighteen more African States ratified the Covenant between 1976 to 1989. ${ }^{5}$ The remaining 23 African States ratified the Covenant from 1990 following increased global attention to the principle of universality, indivisibility, interdependence, and interrelatedness of all human rights ${ }^{6}$ and the adoption of new (democratic and liberal) constitutions in Africa, ${ }^{7}$ protecting (some) ESC rights

\footnotetext{
1 International Covenant on Economic, Social and Cultural Rights (ICESCR), adopted 16 December 1966, entered into force 3 January 1976, 993 UNTS 3.

2 By November 2016 the following 49 African States were State parties to the ICESCR: Algeria, Angola, Benin, Burkina Faso, Burundi, Cape (Cabo) Verde, Cameroon, Central African Republic (CAR), Chad, Congo, Côte d'Ivoire (Ivory Coast), Democratic Republic of Congo (DRC), Djibouti, Egypt, Equatorial Guinea, Eritrea, Ethiopia, Gabon, Gambia, Ghana, Guinea, Guinea-Bissau, Kenya, Lesotho, Liberia, Libya, Madagascar, Malawi, Mali, Mauritania, Mauritius, Morocco, Namibia, Niger, Nigeria, Rwanda, Senegal, Seychelles, Sierra Leone, Somalia, South Africa, Sudan, Swaziland, Togo, Tunisia, Uganda, United Republic of Tanzania, Zambia and Zimbabwe. Comoros and São Tomé and Príncipe had signed the Covenant but had not ratified it. See United Nations Treaty Collection (UNTC), ICESCR, https:// treaties.un.org/doc/Publication/MTDSG/Volume\%20I/Chapter\%20IV/IV-3.en.pdf.

3 Ibid.

4 These were Kenya, Libya, Madagascar, Mali, Mauritania, Rwanda and Tunisia.

5 These were Algeria, Central African Republic, Cameroon, Congo, DRC, Egypt, Gabon, Gambia, Guinea, Equatorial Guinea, Morocco, Niger, Sudan, Senegal, Togo, Uganda, United Republic of Tanzania and Zambia.

6 Vienna Declaration and Programme of Action, adopted by the World Conference on Human Rights in Vienna on 25 June 1993, UN Doc. A/CONF.157/24 (Part I) (13 October 1993) p. 20, para. 5.

7 Prempeh (2007), pp. 469-506.
} 
alongside civil and political rights. ${ }^{8}$ In addition, at least 13 African States had signed the Optional Protocol to the ICESCR by November 2016, though only three of these (Cape Verde, Gabon and Niger) had ratified it. ${ }^{9}$ The Covenant, therefore, enjoys widespread support in Africa at least viewed in terms of ratification.

The focus of the article is limited to examining the influence of the ICESCR in Africa because while African States constitute a significant majority of State parties to the ICESCR, there are no studies engaging with the influence of the Covenant in Africa. The article, therefore, seeks to examine the following questions. What has been the influence of the Covenant on the protection of human rights in Africa at both regional and domestic levels? Has the Covenant had any influence on the African regional human rights instruments? What has been the influence of the Covenant, if any, on the constitutional protection of human rights and on national courts' jurisprudence in Africa?

The influence of the Covenant can be said to come about where something from the Covenant flows into and thereby affects the protection of ESC rights in Africa. This may be reflected in citations of the Covenant by courts and tribunals, treaty provisions or national legislation or policy concluded on the basis of the ICESCR, development of new norms based on the Covenant, such as the right to development, and whether the Covenant has affected human rights teaching, practice, and policy in Africa. The Covenant's influence derives mainly from the obligation of State parties under Article 2(1) ICESCR to 'take steps' (legislative and other measures) to the maximum of available resources, with a view to achieving progressively the full realisation of ESC rights. It is widely accepted that the ratification of international human rights treaties is meaningful if the rights guaranteed in relevant treaties have an effect upon domestic (national or municipal) protection of human rights, and effective remedies for violations of the protected rights are available and accessible, at the domestic level. ${ }^{10}$ Although mere ratification of international treaties by States with worse human rights records without translating them into domestic law and policy does not necessarily result in improved outcomes in terms of human rights realisation and redress of violations, ${ }^{11}$ it might represent 'the initiation, culmination, or reconfiguration of a domestic political struggle' for better human rights practices. ${ }^{12}$

On the occasion of the 50th anniversary of the ICESCR in 2016, this article considers the influence of the ICESCR in Africa, with its focus mainly on the legal

\footnotetext{
${ }^{8}$ Heyns and Kaguongo (2006), pp. 673-717. See also Constitutions of all African States at African Law Library, African Constitutions Collection, http://www.africanlawlibrary.net/web/constitutions/overview; and African Legal Centre, Constitutions of African Countries.

9 These were Angola, Benin, Burkina Faso, Cape (Cabo) Verde, Congo, DRC, Gabon, Ghana, GuineaBissau, Mali, Niger, Senegal and Togo. Three of these States, namely Cape (Cabo) Verde, Gabon and Niger were parties to the Optional Protocol. Central African Republic acceded to the ICESCR on 11 October 2016. See UNTC, Optional Protocol to the ICESCR, https://treaties.un.org/doc/Publication/ MTDSG/Volume\%20I/Chapter\%20IV/IV-3-a.en.pdf.

${ }^{10}$ See Anuak Justice Council v. Ethiopia, Communication No. 299/05, 20th Activity Report, (2006) AHRLR 97, paras. 47-48.

11 Hathaway (2002), p. 1935.

12 Goodman and Jinks (2003) p. 171, at p. 174.
} 
dimension of the Covenant's influence ('legal effects', i.e., the effect of the Covenant on the legal protection of human rights), rather than on the 'actual', statistically or empirically verifiable changes brought about by the Covenant. To place the Covenant in the African regional human rights context, the article begins by discussing in Sect. 2 the influence of the ICESCR on the African regional human rights system. It then goes on to examine in Sect. 3 the influence of the ICESCR upon constitutional protection of human rights in Africa drawing on examples from former British colonies in Africa (applying a 'dualist' approach to the ICESCR) and former French and Portuguese colonies in Africa (applying a 'monist' approach to the ICESCR). It considers whether the rights protected in the ICESCR are part of national ('municipal', 'domestic' or 'internal') constitutional law in African States and, if so, where do these rights feature in the hierarchy of the domestic legal order? The focus is primarily on the influence of the ICESCR on the constitutional protection of ESC rights because this is the most effective means of protecting human rights in Africa. Have rights in the ICESCR been invoked before, or 'applied' by national courts in Africa in their judgments? The article ends in Sect. 4 with some concluding observations about the influence of the Covenant in Africa on the occasion of the 50th anniversary and comments on what needs to be done to maximize the influence of the ICESCR in the future.

\section{Influence of the ICESCR on the African Regional Human Rights System}

At the outset, it must be noted that the ICESCR influenced the drafting, legal protection and development of ESC rights in the African Charter on Human and Peoples' Rights ${ }^{13}$ (African Charter), African Union's primary human rights treaty, adopted on 27 June 1981, 15 years after the adoption of the ICESCR. The African Charter in Articles 15-19 explicitly recognises the following rights, which are protected in the ICESCR: the right of self-determination; the right to work under equitable and satisfactory conditions; the right to enjoy the best attainable state of physical and mental health; the right to education; the protection of the family, and cultural rights. Although the formulation of the rights in the Charter is narrower than in the ICESCR, the Charter protects some individual or collective/group rights not protected in the Covenant. Such rights include the right of all peoples to 'economic, social and cultural development' ${ }^{14}$ and 'the right to a general satisfactory environment favourable to their development'. ${ }^{15}$ Since the scope of the right to development and the right to a clean (satisfactory) environment are not defined in the African Charter, the African Commission on Human and Peoples' Rights (African Commission) has been influenced by international instruments including the ICESCR in interpreting these rights broadly.

\footnotetext{
13 African Charter on Human and Peoples' Rights, OAU Doc. CAB/LEG/67/3 rev. 5, 21 ILM 58 (1982), ratified by 53 member States of the African Union (AU).

14 Ibid., Art. 22.

15 Ibid., Art. 24.
} 
It is important to stress that the African Commission is empowered to "draw inspiration from international law on human and peoples' rights', ${ }^{16}$ particularly from the UN instruments such as the ICESCR, when interpreting the Charter. This provided a legal basis to rely on the ICESCR to develop the jurisprudence of the African Commission on ESC rights. On this basis, the Commission has relied directly or indirectly on the ICESCR to develop the scope and content of ESC rights as well as the corresponding State obligations.

For instance, in its 2016 Resolution on the Right to Education in Africa, the Commission specifically considered Article 13 of the ICESCR and urged African States to 'guarantee the full scope of the right to education', including the 'provision of pre-school, primary, secondary, tertiary, adult education and vocational training'. ${ }^{17}$ Using the wording in Article 2 ICESCR, it called on States to adopt all necessary and 'appropriate' measures to the 'maximum of available resources' to promote, provide and facilitate access to education for all in Africa. ${ }^{18}$ Moreover, in 2010 the Commission adopted principles and guidelines on ESC rights in Africa ${ }^{19}$ largely drawing inspiration from the ICESCR and the UN Committee on Economic Social and Cultural Rights (CESCR or the Committee) General Comments, which have developed the normative content of ESC rights and State obligations since the 1990 s. $^{20}$

Accordingly, the Charter has been interpreted as recognising implicitly other ESC rights (protected by the ICESCR but) not explicitly stated in the Charter, for example the right to an adequate standard of living (adequate food, clothing, housing, water and sanitation), the right to social security, the right to rest and leisure, and the right to form and join trade unions. ${ }^{21}$ This is despite the fact that these rights were deliberately omitted from explicit protection in the African Charter so as to 'spare young states too many but important

\footnotetext{
16 Ibid., Art. 60.

17 Resolution on the Right to Education in Africa, ACHPR/Res.346 (LVIII) 2016, 20 April 2016.

18 Ibid.

19 See African Commission, Principles and Guidelines on the Implementation of Economic, Social and Cultural Rights in the African Charter on Human and Peoples' Rights, adopted at the 47th Ordinary Session of the African Commission held in Banjul, the Gambia, from 12 to 26 May 2010, http://www. achpr.org/files/instruments/economic-social-cultural/achpr_instr_guide_draft_esc_rights_eng.pdf.

${ }^{20}$ The General Comments of the CESCR are available at http://tbinternet.ohchr.org/_layouts/ treatybodyexternal/TBSearch.aspx?Lang=en\&TreatyID=9\&DocTypeID=11.

21 See, e.g., Social and Economic Rights Action Center (SERAC) and Center for Economic and Social Rights (CESR) v. Nigeria, Communication No. 155/96, 15th Annual Activity Report, (2001) AHRLR 60, paras. 60 and 65 (the Commission implied rights to housing or shelter and food in the African Charter); Sudan Human Rights Organisation and Another v. Sudan, Communication Nos. 279/03 and 296/05, 28th Activity Report, (2009) AHRLR 153, para. 212 (the Commission stated that Art. 16 of the African Charter, which protects the right to health, implicitly protects rights to adequate food and housing, including the prohibition on forced evictions, and also guarantees the right to water); African Commission, Guidelines for National Periodic Reports 1989, available at http://www.achpr.org/ instruments/guidelines_national_periodic_reports/, paras. II.A.31-34, para. II.18, paras. 9, 10, and 17; African Commission Resolution on Economic, Social and Cultural Rights in Africa, ACHPR/Res.73 (XXXVI)04 (2004), adopting the 'Statement on Social, Economic and Cultural Rights in Africa', adopted on 17 September 2004, in Pretoria, South Africa, 5 African Human Rights Law Journal (2005), pp. 182193, available at http://www.achpr.org/instruments/pretoria-declaration/, para. 10.
} 
obligations'. ${ }^{22}$ The African Commission has defined the right to development as 'an inalienable, individual or collective right, to participate in all forms of development, through the full realisation of all fundamental rights, and to enjoy them without unjustifiable restrictions'. ${ }^{23}$ It follows that the right to development imposes obligations on States to respect, protect and fulfil 'all fundamental rights' including civil and political rights as well as all ESC rights. Thus the Commission has confirmed that: 'The right to development will be violated when the development in question decreases the well-being of the community'. ${ }^{24}$ Such well-being entails all ESC rights protected in the ICESCR such the right to housing including freedom 'to choose where to live', ${ }^{25}$ right to water and sanitation, ${ }^{26}$ right to adequate food, ${ }^{27}$ and the right to economic selfdetermination, i.e. the right of all peoples to 'freely dispose of their wealth and natural resources'. 28

The content of some treaty provisions protecting ESC rights in other later African Union regional human rights treaties protecting specific vulnerable groups, such as children, women, the youth, internally displaced persons, older persons and persons with disabilities were heavily influenced, at least in part, by the ICESCR. Such treaties include the African Charter on the Rights and Welfare of the Child ${ }^{29}$; the Protocol to the African Charter on Human and Peoples' Rights on the Rights of Women in Africa ${ }^{30}$; the African Youth Charter $^{31}$; the Convention for the Protection

\footnotetext{
${ }^{22}$ See Rapporteur's Report on the Draft African Charter on Human and Peoples' Rights, OAU Doc. CAB/LEG/67/Draft Rapt.Rpt. (II) Rev.4, para. 13.

23 Open Society Justice Initiative v. Côte d'Ivoire, Communication No. 318/06, 17th Extraordinary Session, 19-28 February 2015, para. 183 (emphasis added).

24 Centre for Minority Rights Development (Kenya) and Minority Rights Group (on behalf of Endorois Welfare Council) v. Kenya, Communication No. 276/03, 27th Activity Report, 25 November 2009, para. 294 (emphasis added).

25 Ibid., Art. 278.

26 Ibid., Arts. 87-92.

27 SERAC \& CESR v. Nigeria, above n. 21.

28 Democratic Republic of the Congo v. Burundi, Rwanda and Uganda, Communication No. 227/99, 20th Activity Report, 29 May 2003, para. 95; African Charter, above n. 13, Art. 21.

29 OAU Doc. CAB/LEG/24.9/49 (1990), entered into force 29 November 1999, Art. 11 (right to education); Art. 12 (leisure, recreation and cultural activities); Art. 14 (right to health); Art. 15 (protection against child labour); Art. 18 (protection of the family); and Art. 21 (protection from harmful social and cultural practices). See also Institute for Human Rights and Development in Africa (IHRDA) and Open Society Justice Initiative on Behalf of Children of Nubian Descent in Kenya v. The Government of Kenya, Decision No. 002/Com/002/2009, available at http://acerwc.org/?wpdmdl=8690 (African Committee of Experts on the Rights and Welfare of the Child, 22 March 2011), para. 65.

30 See Protocol to the African Charter on Human and Peoples' Rights on the Rights of Women in Africa, adopted by the Second Ordinary Session of the AU Assembly, Maputo, 11 July 2003, entered into force 25 November 2005, available at http://www.au.int/en/treaties/protocol-african-charter-human-andpeoples-rights-rights-women-africa, Arts. 12-17, 22-24.

31 See African Youth Charter, adopted by the AU Assembly in July 2006, entered into force 8 August 2009, available at http://www.au.int/en/treaties/african-youth-charter, Arts. 13-16, 20 and 25.
} 
and Assistance of Internally Displaced Persons ${ }^{32}$; and the Protocol to the African Charter on Human and Peoples' Rights on the Rights of Older Persons in Africa. ${ }^{33}$ The African Court on Human and Peoples' Rights (or any other court to replace it in the future) will enforce ESC rights protected in the ICESCR since the Protocol to the African Charter on the Establishment of an African Court on Human and Peoples' Rights empowers the African Court to consider 'all cases and disputes submitted to it concerning the interpretation and application of the Charter, this Protocol and any other relevant Human Rights instrument ratified by the States concerned'. ${ }^{34}$ This means that the Court will interpret relevant provisions of the African Charter in light of the provisions of any applicable international human rights instrument to which a State is a party including the International Covenant on Civil and Political Rights (ICCPR), the ICESCR and relevant jurisprudence of human rights bodies. ${ }^{35}$

More recently, the African Court on Human and Peoples' Rights has also confirmed in the African Commission on Human and Peoples' Rights v. Republic of Kenya that by virtue of Articles 60 and 61 of the African Charter it will draw inspiration from 'other human rights instruments' including the ICESCR and the CESCR General Comments to interpret rights protected by the Charter. ${ }^{36}$ In this case the Court found, inter alia, that the Republic of Kenya interfered with the enjoyment of the right to culture of the Ogiek population by evicting them from the Mau Forest in Kenya, thereby, restricting them from exercising their cultural activities and practices, in violation of Article 17(2) and (3) of the African Charter. In arriving at this conclusion, the Court specifically relied on the CESCR General Comment 21 paragraphs 36-37 to interpret the right to take part in cultural life under article 17 of the African Charter observing that:

\footnotetext{
32 African Union Convention for the Protection and Assistance of Internally Displaced Persons in Africa (Kampala Convention), adopted by the Special Summit of the AU held in Kampala, 22 October 2009, entered into force 6 December 2012, available at http://www.au.int/en/treaties/african-union-conventionprotection-and-assistance-internally-displaced-persons-africa, Art. 3(b) requires States to '[p]revent political, social, cultural and economic exclusion and marginalisation, that are likely to cause displacement of populations or persons by virtue of their social identity, religion or political opinion'.

33 Adopted on 31 January 2016, http://www.au.int/en/treaties/protocol-african-charter-human-andpeoples\%E2\%80\%99-rights-rights-older-persons-africa, Arts. 6-17.

${ }^{34}$ Protocol to the African Charter on Human and Peoples' Rights on the Establishment of an African Court on Human and Peoples' Rights, AU Doc. OAU/LEG/EXP/AFCHPR/PROT (III), adopted on 10 June 1998, entered into force 25 January 2004, Arts. 3 and 7. See also the Protocol on the Statute of the African Court of Justice and Human Rights, adopted on 1 July 2008, available at http://www.au.int/en/ treaties/protocol-statute-african-court-justice-and-human-rights, Art. 28 (c).

35 See, e.g., In the Matter of Alex Thomas v. United Republic of Tanzania, Application No. 005/2013 (African Court on Human and Peoples' Rights, 12 November 2015), paras. 88, 95-98, 114-121, 124, 130, 146, and 158 in which the court relied on Art. 14(3)(d) of the ICCPR, decisions of the African Commission, judgments of the European Court of Human Rights and Inter-American Court of Human Rights as well as views of the Human Rights Committee. See also Wilfred Onyango Nganyi and 9 Others v. United Republic of Tanzania, Application No. 006/2013 (African Court on Human and Peoples' Rights, 18 March 2016), available at http://en.african-court.org/images/Cases/Judgment/Onyango_Judgment.pdf, paras. 165-179; In the Matter of Actions Pour La Protection Des Droits De L'Homme (APDH) v. Republic of Cote D'ivoire, Application No. 001/2014 (African Court on Human and Peoples' Rights, 18 November 2016).
}

${ }^{36}$ African Commission on Human and Peoples' Rights v. Republic of Kenya, Application No. 006/2012 (African Court on Human and Peoples' Rights, Judgment of 26 May 2017), para. 108. 
The UN Committee on Economic, Social and Cultural Rights, in its General Comment on Article 15(1) (a) also observed that 'the strong communal dimension of indigenous peoples' cultural life is indispensable to their existence, well-being and full-development, and includes the right to the lands, territories and resources which they have traditionally owned, occupied or otherwise used or acquired'. ${ }^{37}$

As a result, the Court accepted that the Ogiek population as Indigenous Peoples had the right to occupy their ancestral lands in the Mau Forest, as well as the right to use and enjoy the said lands. Given that approximately 50 million indigenous peoples live across Africa and face high levels of economic, social and cultural marginalisation, ${ }^{38}$ the African Court's judgment relating to the Ogiek population provides a good illustration of how litigation can support the legal empowerment of marginalised groups such as indigenous peoples in Africa.

Similarly the Human and Peoples' Rights Section of the African Court of Justice and Human and Peoples Rights, which will replace the existing African Court on Human and Peoples' Rights after ratification of the Court's Statute by 15 States, shall be competent to hear 'all cases relating to human and peoples' rights' including cases alleging violations of ESC rights. ${ }^{39}$ However, the limitation placed on direct access to the Court by victims of human rights violations, namely individuals and non-governmental organizations (NGOs) will limit the Court's effectiveness. ${ }^{40}$ This is because direct access to the Court is limited to 'individuals or relevant NGOs accredited to the African Union or to its organs' where a State concerned has submitted an optional declaration accepting the competence of the Court to receive cases from individuals and NGOs. ${ }^{41}$ It is important to note that States have been reluctant to make such a declaration to accept the jurisdiction of the existing African Court on Human and Peoples' Rights to receive cases of human rights violations directly from individuals and NGOs. As at May 2017, only eight (8) of the thirty (30) States parties to the Protocol to the African Charter on Human and Peoples' Rights on the Establishment of an African Court on Human and Peoples' Rights had made the declaration recognising the competence of the Court to receive cases from individuals and NGOs. ${ }^{42}$ The eight (8) States were Benin, Burkina Faso, Côte d'Ivoire, Ghana, Mali, Malawi, Tanzania and Tunisia. Without such a declaration, the Court manifestly lacks jurisdiction to receive cases from

\footnotetext{
37 Ibid., para. 181.

38 See International Work Group on Indigenous Affairs, http://www.iwgia.org/regions/africa.

39 See Statute of the African Court of Justice and Human and Peoples Rights, adopted 27 June 2014, Art. 17(2), https://www.au.int/web/sites/default/files/treaties/7804-treaty-0045_-_protocol_on_amendments_ to_the_protocol_on_the_statute_of_the_african_court_of_justice_and_human_rights_e.pdf.

40 Ibid., Art. 9(3).

41 Protocol on the Statute of the African Court of Justice and Human Rights, adopted 1 July 2008, Art. 8(3); Statute of the African Court of Justice and Human Rights, adopted 1 July 2008, Art. 30(f).

42 See African Court on Human and Peoples' Rights, http://www.african-court.org/en/. The 30 States which had ratified the Protocol by May 2017 were: Algeria, Benin, Burkina Faso, Burundi, Cameroon, Chad, Côte d'Ivoire, Comoros, Congo, Gabon, Gambia, Ghana, Kenya, Libya, Lesotho, Mali, Malawi, Mozambique, Mauritania, Mauritius, Nigeria, Niger, Rwanda, Sahrawi Arab Democratic Republic, South Africa, Senegal, Tanzania, Togo, Tunisia and Uganda.
} 
individuals and NGOs alleging violations of ESC rights against several States. This limits the Court's potential to develop ESC rights protection on the basis of relevant human rights treaties including the ICESCR.

Furthermore, requests for the advisory opinions from NGOs are limited to 'any African organisation recognised by the AU'. ${ }^{43}$ This has been understood to refer to African NGOs 'with observer status before or a Memorandum of Understanding with the African Union [AU]'. ${ }^{44}$ However, most human rights NGOs cannot obtain such observer status before the AU because the 'granting, suspension and withdrawal of observer status of an NGO, are the prerogative of the African Union and shall not be subject of adjudication in any Court of Law or tribunal'. ${ }^{45}$ Accordingly, NGOs not recognised by the Executive Council of the AU are not entitled to bring requests for advisory opinions before the African Court. This is a missed opportunity to request the Court's advisory opinions on issues relevant to ESC rights.

The African Charter, which entered into force on 21 October 1986, nearly 10 years after entry into force of the ICESCR, placed legally binding obligations on State parties and obliged them to 'recognize the rights, duties and freedoms' enshrined in the Charter and 'undertake to adopt legislative or other measures to give effect to them'. ${ }^{46}$ This entails obligations to 'respect', 'protect' and 'fulfil' all rights protected by the African Charter including ESC rights. ${ }^{47}$ Thus the Charter's preamble reaffirmed that:

civil and political rights cannot be dissociated from economic, social and cultural rights in their conception as well as universality and that the satisfaction of economic, social and cultural rights is a guarantee for the enjoyment of civil and political rights. ${ }^{48}$

The African Commission has thus interpreted civil and political rights broadly to include ESC rights. For example the right to life under article 4 of the African Charter" ${ }^{49}$ has been understood to entail a 'dignified

\footnotetext{
43 Protocol on the Statute of the African Court of Justice and Human Rights, above n. 41, Art. 4(1).

44 See Request for Advisory Opinion by the Socio-Economic Rights and Accountability Project (SERAP), No. 001/2013, Advisory Opinion, 26 May 2017, para. 64.

45 See Criteria for Granting Observer Status and for a System of Accreditation within the AU, EX.CL/ 195 (VII) Annex V adopted by the 7th Ordinary Session of the Executive Council and Endorsed by the 5th Ordinary Session of the AU Assembly held in Sirte, Libya, on 1-2 and 4-5 July 2005, respectively, sect. V, 6.

46 African Charter, above n. 13, Art. 1.

47 See, e.g., Abdel Hadi, Ali Radi and Others v. Sudan, Communication No. 368/09, 5 November 2013, para. 92: 'The Commission considers that if a State Party fails to respect, protect, promote or fulfil any of the rights guaranteed in the Charter, this constitutes a violation of Article 1 of African Charter'. See also Social and Economic Rights Action Center and Center for Economic and Social Rights v. Nigeria, Communication No. 155/96, 15th Annual Activity Report, (2001) AHRLR 60 (ACHPR 2001), paras. 44-47; Zimbabwe Human Rights NGO Forum v. Zimbabwe, Communication No. 245/2002, Annex III, (2006) 21st Activity Report, (2006) AHRLR 128 (ACHPR 2006), para. 152.

48 African Charter, above n. 13, preamble, para. 8.

49 Ibid., Art. 4 reads: 'Human beings are inviolable. Every human being shall be entitled to respect for his life and the integrity of his person. No one may be arbitrarily deprived of this right'.
} 
life'. ${ }^{50}$ This includes State obligations to take 'preventive steps to preserve and protect the natural environment and humanitarian responses to natural disasters, famines, outbreaks of infectious diseases, or other emergencies' ${ }^{51}$ In addition, the Commission has interpreted the right to life to entail State obligations 'to address more chronic yet pervasive threats to life, for example with respect to preventable maternal mortality, by establishing functioning health systems and eliminating discriminatory laws and practices which impact on individuals' and groups' ability to seek healthcare'. ${ }^{52}$ Thus, the Commission has noted that violations of ESC rights may in certain circumstances also entail violations of the right to life. ${ }^{53}$ It is crucially important to note that the African Commission has strongly recommended that African States 'harmonize' domestic legislation with 'international human rights obligations'. 54 Have African State parties to the ICESCR harmonised their domestic laws with the ICESCR? The next section examines the influence of the ICESCR on domestic legal regimes in Africa with particular emphasis on the whether the Covenant has influenced the constitutional protection of human rights.

\section{Influence of the ICESCR on the Domestic Protection of Human Rights in Africa}

Although many African States are notoriously late submitting their reports to the CESCR, it is crucial to note that the Committee has made several important recommendations on the domestic implementation of ESC rights in several African States. ${ }^{55}$ It is notable from these observations that a common issue of concern in

\footnotetext{
${ }^{50}$ See African Commission, General Comment No. 3 on the African Charter on Human and Peoples' Rights: The Right to Life (Article 4) (November 2015), available at http://www.achpr.org/instruments/ general-comments-right-to-life/, paras. 3 and 43 .

51 Ibid., at para. 41.

52 Ibid., at para. 42.

53 Ibid., at para. 43.

54 See, e.g., Groupe de Travail sur les Dossiers Judiciaires Stratégiques v. Democratic Republic of Congo, Communication No. 259/2002 (2011), available at http://www.achpr.org/files/sessions/14th-eo/ comunications/259.2002/achpr14eos_decision_259_02_eng.pdf, para. 92(i).

55 See, e.g., the following Concluding Observations of the CESCR on the following States: Algeria, UN Docs. E/C.12/1995/17 (28 December 1995), E/C.12/1995/18 (7 October 1996) paras. 278-305, E/C.12/1/ Add.71 (30 November 2001), E/C.12/DZA/CO/4 (7 June 2010); Angola, UN Doc. E/C.12/AGO/CO/3 (1 December 2008); Benin, UN Docs. E/C.12/1/Add.78 (5 June 2002), E/C.12/BEN/CO/2 (9 June 2008); Burundi, UN Doc. E/C.12/BDI/CO/1 (16 October 2015); Cameroon, UN Docs. E/C.12/1989/5 (1989) paras. 53-78, E/C.12/CMR/CO/2-3 (23 January 2012); Chad, UN Doc. E/C.12/TCD/CO/3 (16 December 2009); Congo, UN Docs. E/C.12/1/Add.45 (23 May 2000), E/C.12/COG/CO/1 (2 January 2013); Democratic Republic of the Congo, UN Docs. E/C.12/1988/4 (1988) paras. 270-303, E/C.12/COD/CO/4 (16 December 2009); Djibouti, UN Doc. E/C.12/DJI/CO/1-2 (30 December 2013); Egypt, UN Docs. E/C.12/1/Add.44 (23 May 2000), E/C.12/EGY/CO/2-4 (13 December 2013); Equatorial Guinea, UN Doc. E/C.12/GNQ/CO/1 (13 December 2012); Ethiopia, UN Doc. E/C.12/ETH/CO/1-3 (31 May 2012); Gabon, UN Doc. E/C.12/GAB/CO/1 (27 December 2013); Gambia, UN Doc. E/C.12/1994/9 (31 May 1994); Guinea, UN Doc. E/C.12/1/Add.5 (28 May 1996); Kenya, UN Docs. E/C.12/1993/6 (3 June 1993), E/1995/22 (SUPP) (1995) paras. 159-164, E/C.12/KEN/CO/1 (1 December 2008), E/C.12/KEN/CO/2-5 (4 March 2016); Libya, UN Docs. E/1983/WG.1/SR.16 (3 May 1983), E/1983/WG.1/SR.17 (3 May
} 
Africa relates to the domestic application of the ICESCR. This section begins by examining whether the rights protected in the ICESCR are part of domestic constitutions in Africa followed by an evaluation of domestic approaches to the application of the ICESCR in Africa, in States applying dualist and monist approaches to international treaties in Africa.

\subsection{Are the Rights Protected in the ICESCR Part of Domestic Constitutions in Africa?}

State parties to the ICESCR are obliged to 'take steps' to the maximum of 'available resources', with a view to 'achieving progressively' the full realisation of the rights recognised in the Covenant. ${ }^{56}$ This must be done by all 'appropriate means, including particularly the adoption of legislative measures' ${ }^{57}$ While it is recognised that the ICESCR 'does not formally oblige States to incorporate its provisions in domestic law' and thus there is no obligation to adopt or incorporate the Covenant in national constitution or other national laws, direct incorporation is highly desirable since it 'avoids problems that might arise in the translation of treaty obligations into national law, and provides a basis for the direct invocation of the Covenant rights by individuals in national courts' ${ }^{58}$

Some African States have adopted constitutional provisions in the post-1990 era, usually after becoming State parties to the ICESCR, according priority to the provisions of international human rights treaties, including the ICESCR, over any inconsistent domestic laws. For example, under Article 2(6) of Kenya's 2010 Constitution: 'Any

\section{Footnote 55 continued}

1983), E/C.12/1/Add.15 (20 May 1997), E/C.12/LYB/CO/2 (25 January 2006); Madagascar, UN Doc. E/C.12/MDG/CO/2 (16 December 2009); Mali, UN Doc. E/C.12/1994/17 (21 December 1994); Mauritania, UN Doc. E/C.12/MRT/CO/1 (10 December 2012); Mauritius, UN Doc. E/C.12/MUS/CO/4 (8 June 2010); Morocco, UN Docs. E/C.12/1994/5 (30 May 1994), E/1995/22 (SUPP) (1995) paras. 101-124, E/C.12/1/Add.55 (1 December 2000), E/C.12/MAR/CO/3 (4 September 2006), E/C.12/MAR/CO/2 (4 September 2006), E/C.12/MAR/CO/4 (9 October 2015); Namibia, UN Doc. E/C.12/NAM/CO/1 (4 March 2016); Nigeria, UN Doc. E/C.12/1/Add.23 (16 June 1998); Rwanda, UN Docs. E/1984/WG.1/SR.10 (27 April 1984), E/1984/WG.1/SR.12 (30 April 1984), E/C.12/1989/5 (1989) paras. 162-192, E/C.12/RWA/ CO/2-4 (10 June 2013); Senegal, UN Docs. E/1981/WG.1/SR.11 (11 September 1981), E/C.12/1993/18 (5 January 1994), E/C.12/1/Add.62 (24 September 2001); Sudan, UN Docs. E/C.12/1/Add.48 (1 September 2000), E/C.12/SDN/CO/2 (27 October 2015); Togo, UN Docs. E/C.12/1/Add.61 (21 May 2001), E/C.12/TGO/CO/1 (3 June 2013); Tunisia, UN Docs. E/1980/WG.1/SR.5 (18 April 1980), E/1980/ WG.1/SR.6 (21 April 1980), E/C.12/1/Add.36 (14 May 1999), E/C.12/TUN/CO/3 (14 November 2016); Uganda, UN Doc. E/C.12/UGA/CO/1 (24 June 2015); United Republic of Tanzania, UN Docs. E/1980/ WG.1/SR.5 (18 April 1980), E/C.12/TZA/CO/1-3 (13 December 2012); Zambia, UN Docs. E/1986/ WG.1/SR.4 (18 April 1986), E/1986/WG.1/SR.5 (22 April 1986), E/1986/WG.1/SR.7 (23 April 1986), E/C.12/1/Add.106 (23 June 2005); and Zimbabwe, UN Doc. E/C.12/1/Add.12 (20 May 1997). The CESCR Concluding Observations, are available at http://tbinternet.ohchr.org/_layouts/ treatybodyexternal/TBSearch.aspx?Lang=en\&TreatyID=9\&DocTypeID=5.

56 ICESCR, above n. 1, Art. 2(1); Committee on Economic, Social and Cultural Rights (CESCR), General Comment 3: The Nature of States Parties' Obligations, UN Doc. E/1991/23, annex III at 86 (1990); Mohamed Ben Djazia and Naouel Bellili (represented by Javier Rubio) v. Spain, Communication No. 5/2015, E/C.12/61/D/5/2015 (20 June 2017).

57 Ibid.

58 CESCR, General Comment 9: The Domestic Application of the Covenant, UN Doc. E/C.12/1998/24 (3 December 1998) para. 8. 
treaty or convention ratified by Kenya shall form part of the law of Kenya under this Constitution'. As Kenya ratified the ICESCR, it is 'part of' domestic Kenyan law. Some State constitutions affirm commitment to human rights enshrined in 'all duly ratified international conventions' including the ICESCR without a detailed explicit Bill of Rights. ${ }^{59}$ However, in practice the ICESCR 'has never been invoked in court decisions, even though it takes precedence over domestic law' ${ }^{60}$ Other States have transformed some rights protected in the Covenant into domestic law by supplementing or amending existing national constitutions and ordinary legislation, without invoking the specific terms of the Covenant. Due to weak parliamentary institutions in most of Africa overly dependent on the executive, there is lack of domesticating legislation of international human rights treaties including the ICESCR. Judges do not frequently rely on or reference to the ICESCR in their judgments in national cases, and only in the rarest of occasions do they refer to the jurisprudence (general comments, concluding observations, and views) of the CESCR.

As noted above, while the Committee has made several important recommendations on the implementation of ESC rights in several African States, ${ }^{61}$ the influence of these recommendations in Africa generally remains limited since most of them remain unimplemented or unduly delayed. This is partly because of lack of political will to comply with the recommendations of international (quasi)-judicial bodies. For example, States have been reluctant to implement the recommendations of the African Commission relating to ESC rights, such as the Commission's decision on the Endorois. ${ }^{62}$ This is worsened by the lack of effective follow-up with the concluding observations and recommendations of the Committee concerning previous reports. In addition, several African States still consider the Committee's recommendations to be 'non-binding' under international law. Consequently, States have done very little to disseminate the Committee's concluding observations widely. Thus, most African victims of violations of ESC rights do not know of the existence of the ICESCR. In addition, most African States regard most ESC rights (particularly adequate housing, food, water and sanitation) as merely non-justiciable 'directive principles' of State policy ('needs' or 'services') rather than fully justiciable human rights ('entitlements'). ${ }^{63}$ Thus some national constitutions

\footnotetext{
59 See, e.g., the Constitution of the Republic of Cameroon (revised 2008), preamble.

${ }^{60}$ CESCR, Concluding Observations: Cameroon, UN Doc. E/C.12/CMR/CO/2-3 (23 January 2012) para. 7.

61 See, e.g., Concluding Observations of the CESCR, above n. 55.

62 Centre for Minority Rights Development (Kenya) and Another on Behalf of the Endorois Welfare Council v. Kenya, Communication No. 276/2003, 27th Activity Report, (2009) AHRLR 75 (ACHPR 2009); CESCR, Concluding Observations: Kenya, UN Doc. E/C.12/KEN/CO/2-5 (4 March 2016) paras. 15-16; Murray and Long (2015).

63 See, e.g., Constitutions of Nigeria (1999), Lesotho (1993), Sierra Leone (1991), Ghana (1992), Ethiopia (1994), Uganda (1995) and the Gambia (1996). See also Khathang Tema Baitsokoli and Another v. Maseru City Council and Others, Case (CIV) 4/05, CONST/C/1/2004 (Court of Appeal of Lesotho, 20 April 2004), (2004) AHRLR 195; Issa Iddi Abass \& Others v. Accra Metropolitan Assembly and Anor, Suit No. Misc 1203/2002 (Justice Yaw Appau, High Court of Ghana, Accra, 24 July 2002); New Patriotic Party v. Attorney-General [1996-97] SCGLR 729 (Supreme Court of Ghana, Accra). But see Ghana Lotto Operators Association \& Others v. National Lottery Authority [2007-2008] 2 SCGLR 1088, at 1113, the Supreme Court of Ghana held that 'a presumption of justiciability' applies to all provisions of the constitution including to ESC rights confined in the directive principles of State policy.
} 
relegate rights to health and education to non-justiciable 'Principles of State Policy'. ${ }^{64}$ Moreover, even a few States (Nigeria and Benin) ${ }^{65}$ which have expressly given domestic effect to the African Charter ${ }^{66}$ still consider most ESC rights, including the right to free and compulsory primary education, as non-justiciable directive principles of State policy. ${ }^{67}$ As a result, domestic courts in several States have been unwilling to enforce ESC rights claiming that they involve (nonjusticiable) questions of 'a political nature'. ${ }^{68}$ This view has been rejected by the Economic Community of West African States (ECOWAS) Community Court of Justice. In 2009 the Court held that although the right to education was recognised as a non-justiciable 'directive principle' of State policy under section 6(6)(c) of Nigeria's Constitution 1999, the ECOWAS Community obligations undertaken by Nigeria as a result of being a State party to the African Charter (and the ICESCR) mean that the Court was obliged to apply all the rights protected in the African Charter including Article 17 thereof which guarantees the right to education. ${ }^{69}$ Thus the Court confirmed that the rights guaranteed by the African Charter are justiciable before the ECOWAS Court.

As a matter of international law, every State party to a treaty without reservations (including every State organ, e.g., judiciary, parliament, executive) is legally obliged to perform its obligations in 'good faith'. ${ }^{70}$ Thus, a State party to the ICESCR may not invoke the provisions of its domestic law as 'justification for its failure to perform a treaty'. ${ }^{71}$ Rather a State which has contracted valid international obligations, including those arising under the ICESCR, is 'bound to make in its

\footnotetext{
64 Lesotho Constitution (1993), Arts. 27-28.

65 See African Charter on Human and Peoples' Rights (Ratification and Enforcement) Act, Cap 10, Laws of the Federation of Nigeria 1990; and Constitution of the People's Republic of Benin (1990), Art. 7.

66 Above n. 13.

67 See Constitution of the Federal Republic of Nigeria (1999), sects. 6(6)(c) and 18; Registered Trustees of Socio-Economic Rights and Accountability Project (SERAP) v. Federal Republic of Nigeria and Universal Basic Education Commission, ECW/CCJ/APP/12/07, ECW/CCJ/JUD/07/10 (ECOWAS Community Court, 30 November 2010); Socio-Economic Rights and Accountability Project v. Nigeria, Communication No. 300/2005, 25th Activity Report, (2008) AHRLR 108 (ACHPR 2008), paras. 28, 29, 62-69.

68 See, e.g., Centre for Health, Human Rights and Development and 3 Others v. Attorney General, Constitutional Petition No. 16 of 2011, [2012] UGCC 4 (Constitutional Court of Uganda, 5 June 2012), http://www.ulii.org/ug/judgment/constitutional-court/2012/4. But see Centre for Health, Human Rights and Development \& 3 Others v. Attorney General, Constitutional Appeal No. 1 of 2013 (Supreme Court of Uganda, 30 October 2015) directing the Constitutional Court to hear the case on its merits before deciding whether it raised a 'political question'.

69 Registered Trustees of the Socio-economic Rights \& Accountability Project (SERAP) v. The Federal Republic of Nigeria and Universal Basic Education Commission, ECW/CCJ/APP/0808 (ECOWAS Community Court, 27 October 2009), para. 19. Under Art. 4(g) of the Revised Treaty of ECOWAS, http://www.ecowas.int/wp-content/uploads/2015/01/Revised-treaty.pdf, Member States of ECOWAS, affirmed and declared their adherence to the 'recognition, promotion and protection of human and peoples' rights in accordance with the provisions of the African Charter on Human and Peoples' Rights'.

70 Vienna Convention on the Law of Treaties, 23 May 1969, 1155 UNTS 331, 8 ILM 679, Art. 26.

71 Ibid., Art. 27. The ICJ stated that Art. 27 of the Vienna Convention on the Law of Treaties reflects 'customary law', which binds all States. See the Questions Relating to the Obligation to Prosecute or Extradite case (Belgium v. Senegal), ICJ Reports 2012, p. 422, at p. 460.
} 
legislation such modifications as may be necessary to ensure the fulfilment of the obligations undertaken' ${ }^{72}$ The ICESCR does not specify the specific means by which it is to be given effect or implemented in the national legal order. ${ }^{73}$ As a result, every State enjoys a 'margin of discretion' ${ }^{74}$ in adopting 'all appropriate means' to comply with its obligations under the ICESCR. Nevertheless 'legislative measures ${ }^{75}$ (e.g. legislation aimed at preventing violations of ESC rights, such as prohibiting discrimination by non-State actors in the exercise of ESC rights both domestically and, to the extent compatible with international law, extraterritorially; repeal or reform of laws that nullify or impair certain individual's and group's right to realise their ESC rights including sexual and reproductive health, legal prohibition of harmful practices and legal prohibition of harassment at work) ${ }^{76}$ are in many instances 'highly desirable' and in some cases may even be 'indispensable'. ${ }^{77}$ Such legislative measures should provide for appropriate means of redress to aggrieved individuals or groups, or 'accessible, affordable, timely and effective' remedies and to reparation (in the form of restitution, compensation, rehabilitation, satisfaction, and guarantee of non-repetition) for victims of violations, preferably through courts, to ensure accountability. ${ }^{78}$

The ICESCR has influenced the legal protection of ESC rights in some African States in several ways. First, it has been applied as a source of interpretation in some court judgments. Second, it has influenced the content of ESC rights in national constitutions. ${ }^{79}$ Third, it has specifically been referred to as a source of law in some national constitutions and this has in turn influenced the adoption of some ordinary legislation and policies essential to ESC rights. All African States have constitutions containing provisions regulating the relation between international treaties and national law and/or protecting human rights including the right to life, human dignity, equality and non-discrimination, freedom from torture, inhuman and degrading treatment, and some ESC rights. ${ }^{80}$ Although there is no uniform identical approach to treaties in Africa, generally African States apply the 'dualist' or

\footnotetext{
72 See Exchange of Greek and Turkish Population case, Advisory Opinion (21 February 1925), PCIJ Reports, Series B, No. 10, 20.

73 CESCR, General Comment 9, above n. 58, para. 5.

74 CESCR, General Comment 16: The Equal Right of Men and Women to the Enjoyment of all Economic, Social and Cultural Rights, UN Doc. E/C.12/2005/4 (11 August 2005) para. 32.

75 ICESCR, above n. 1, Art. 2(1).

76 CESCR, General Comment 24 on State Obligations under the ICESCR in the Context of Business Activities, UN Doc E/C.12/GC/24 (23 June 2017); CESCR, General Comment 23: The Right to Just and Favourable Conditions of Work, UN Doc. E/C.12/GC/23 (8 March 2016) paras. 50 and 65(e); CESCR, General Comment 22: The Right to Sexual and Reproductive Health, UN Doc. E/C.12/GC/22 (4 March 2016) paras. 34 and 49(a) and (b).

77 CESCR, General Comment 3, above n. 56, para. 3.

78 Universal Declaration of Human Rights, GA Res. 217A (III), UN Doc. A/810 at 71 (1948), Art. 8; CESCR, General Comment 9, above n. 58, paras. 2 and 9; Basic Principles and Guidelines on the Right to a Remedy and Reparation for Victims of Gross Violations of International Human Rights Law and Serious Violations of International Humanitarian Law, A/RES/60/147 (21 March 2005), Art. 3(a)-(d).

79 All African States have bills of rights in constitutions. See African Legal Centre, above n. 8; Chitimira (2017).

80 African Legal Centre, above n. 8.
} 
'monist' approach to international treaties, ${ }^{81}$ following the practice to domestication of international treaties applied by former colonial powers in Africa mainly Britain, France and Portugal, though many constitutions embody both 'dualist' or 'monist' elements.

\subsection{Dualist Approach to the ICESCR in Africa and Influence on Human Rights}

The influence of the ICESCR in African States applying a 'dualist' approach to international treaties has depended on whether or not a particular State has adopted relevant domestic law (constitutional provisions or ordinary legislation) to give effect to its obligations under the Covenant. Generally dualist theoretical approach to the relationship between international and national law takes the view that international law regulates the relations between States whereas national law regulates the rights and obligations of individuals within a State. ${ }^{82}$ In 'dualist' African States, mainly former colonies of the United Kingdom (UK) following the constitutional law of the $\mathrm{UK}^{83}$ the principle is generally that while ' $[\mathrm{t}] \mathrm{he}$ Government may negotiate, conclude, construe, observe, breach, repudiate or terminate a treaty, ${ }^{84}$ such a treaty is not part of domestic law until it has been incorporated by legislation. ${ }^{85}$ The dualist approach takes the view that international courts apply international law while domestic courts are obliged to apply domestic law and not international treaties, or at least that it is for the national court to decide which rule to apply. ${ }^{86}$ Thus, international treaties such as the ICESCR, in whole or in part, are not applicable in any national legal system (and thus not ordinarily enforceable by the courts) unless they have been incorporated into national law (through incorporation or reception) by legislation in force to give effect to them. ${ }^{87}$ The rationale for the dualist theory is to prevent the Executive from being able to

\footnotetext{
${ }^{81}$ For a discussion of the relationship between international treaties and domestic law, see Aust (2013), pp. 159-177; Crawford (2012), pp. 48-111; Shaw (2014), pp. 92-141; and Harris and Sivakumaran (2015), pp. 59-84.

82 Crawford (2012), p. 48.

83 Dicey (1915). Former British colonies in Africa are: Botswana, Cameroon, the Gambia, Ghana, Kenya, Lesotho, Malawi, Mauritius, Mozambique, Namibia, Nigeria, Seychelles, Sierra Leone, South Africa, Swaziland, Tanzania, Uganda, Zambia and Zimbabwe.

84 J.H. Rayner (Mincing Lane) Ltd v. Department of Trade and Industry [1990] 2 AC 418 at 476.

85 Lord Oliver in Maclaine Watson v. Dept. of Trade [1990] 2 AC 418 at 500 (House of Lords) explained that 'a treaty is not part of English law unless and until it has been incorporated into the [domestic] law by legislation'.

86 Crawford (2012), p. 48.

87 See, e.g., the Constitution of the Kingdom of Swaziland (2005), Sect. 238(4) provides that: 'Unless it is self-executing, an international agreement becomes law in Swaziland only when enacted into law by Parliament'; Constitution of the Republic of South Africa 1996, Sect. 231(4): 'Any international agreement becomes law in the Republic when it is enacted into law by national legislation; but a selfexecuting provision of an agreement that has been approved by Parliament is law in the Republic unless it is inconsistent with the Constitution or an Act of Parliament'; Glenister v. President of the Republic of South Africa and Others (CCT 48/10), [2011] ZACC 6 (17 March 2011), para. 92; Azanian Peoples Organization (AZAPO) and Others v. President of the Republic of South Africa and Others (CCT 17/96), [1996] ZACC 16, para. 26.
} 
create law without observing the domestic constitutional requirements necessary for law making (i.e. to prevent law creation by the Executive without an Act of Parliament). ${ }^{88}$ In such States applying a 'dualist' approach to the ICESCR, the Covenant is applied by domestic courts as mediated by national legislation, and national legislation will prevail, unless the issue can be resolved by interpretation. This means that in 'dualist' States in Africa the rights protected under the ICESCR and jurisprudence developed by the CESCR are generally regarded as not directly enforceable unless incorporated into domestic law by legislation.

Furthermore, the influence of the Covenant has also depended on judicial attitude to the application of international treaties by domestic courts. Although some constitutions of 'dualist' States, such as Namibia, provide that 'the general rules of public international law and international agreements' are binding and form part of domestic law, ${ }^{89}$ domestic courts have shown unwillingness to invoke international human rights treaties including the ICESCR. ${ }^{90}$ For example the Supreme Court of Namibia stated in one case that an international treaty ratified by Namibia (in this case the Convention on the Elimination of All Forms of Discrimination against Women ${ }^{91}$ ) was 'subject to the Constitution and cannot change the situation"92 relating to Namibia's legislation, which discriminated on the basis of sex, in relation to the right of male or female persons to assume the surname of the other spouse on marriage. ${ }^{93}$ This led the UN Human Rights Committee to find a violation of the right to equal protection of the law without any discrimination under Article 26 of the ICCPR. ${ }^{94}$

By December 2016, although most African States applying a 'dualist' approach to international treaties had adopted some policy and legislative measures (constitutional provisions and/or ordinary domestic legislation) protecting some aspects of ESC rights, they had not enacted domestic legislation to explicitly and fully incorporate or give full effect to the ICESCR into national laws so as to ensure the applicability of all Covenant rights in domestic courts. ${ }^{95}$ This nondomestication approach also generally applied to other international and regional human rights treaties. As noted above, Nigeria explicitly incorporated the African

\footnotetext{
88 See, e.g., Re McKerr [2004] UKHL 12, Lord Steyn; $R$ v. Jones [2006] 2 WLR 772, Lord Bingham; $R$ (Bancoult) v. Secretary of State for Foreign and Commonwealth Affairs (No. 2) [2009] AC 453, para. 44, Lord Hoffmann; Dicey (1915), p. 38: Parliament has 'the right to make or unmake any law whatsoever; and further, no person or body is recognised by the law as having a right to override or set aside the legislation of Parliament'.

89 Constitution of the Republic of Namibia (1990), Art. 144.

90 See CESCR, Concluding Observations: Namibia, UN Doc. E/C.12/NAM/CO/1 (4 March 2016) para. 6. See also Michael Andreas Müller and Imke Engelhard v. Namibia, Communication No. 919/2000, UN Doc. CCPR/C/74/D/919/2000 (28 June 2002).

91 UN Doc. A/34/46; 1249 UNTS 13; 19 ILM 33 (1980), entered into force 3 September 1981.

92 Michael Andreas Muller v. President of Namibia, SA 2/98, [1999] NASC 2, 200 (6) BCLR 655 (Supreme Court of Namibia, 21 May 1999), http://www.saflii.org/na/cases/NASC/1999/2.html.

93 Section 9 of the Aliens Act No. 1 of 1937 as amended by Proclamation A.G. No. 15 of 1989.

94 Müller v. Namibia, above n. 90, para. 6.8.

95 See, e.g., CESCR, Concluding Observations: Uganda, UN Doc. E/C.12/UGA/CO/1 (24 June 2015) paras. 4-5; CESCR, Concluding Observations: Kenya, UN Doc. E/C.12/KEN/CO/2-5 (4 March 2016 2016) paras. 5-6.
} 
Charter $^{96}$ in Nigeria in 1990 by providing that the African Charter provisions 'have force of law in Nigeria and shall be given full recognition and effect and be applied by all authorities and persons exercising legislative, executive or judicial powers in Nigeria', ${ }^{97}$ more than 25 years later, it had not extended the same treatment to the ICESCR. It remains unclear why the Nigerian authorities deemed it 'necessary and expedient' 98 to incorporate the African Charter, thereby making it possible for domestic courts to 'apply' directly the Charter and open to individuals and groups to 'resort to its [Charter's] provisions to obtain redress in our [Nigerian] domestic courts', 99 but this approach was not extended to the ICESCR.

It is well-known that most 'dualist' African States adopted constitutions, as a precondition to independence, with the Bill of Rights drawing heavily from the [European] Convention for the Protection of Human Rights and Fundamental Freedoms, ${ }^{100}$ with exclusive protection of civil and political rights and the right to property of nationals of the former colonial power. ${ }^{101}$ Thus, historically some domestic courts in 'dualist' African States have referred to international treaties protecting civil and political rights, such as the ICCPR rather than to the ICESCR, when applying and interpreting relevant domestic law. ${ }^{102}$ Given increased attention to the need to address widespread poverty, inequitable distribution of resources and systematic or widespread violations of ESC rights (e.g. education, health, adequate food, housing, water and sanitation) in many African States, several States adopted new constitutions and other domestic legislation since 1990s protecting at least some ESC rights particularly of vulnerable and marginalised groups ${ }^{103}$ influenced in part by (though without explicitly making reference to) the ICESCR.

To date, in many African States, there have been no cases in which the ICESCR has been applied before domestic courts. For this reason, there has been no ESC rights jurisprudence to discuss in this article. However, domestic courts in Africa have handed down significant judgments protecting some aspects of ESC rights. These include cases involving reproductive and sexual rights ${ }^{104}$; the protection of pregnant

\footnotetext{
96 Above n. 13.

97 African Charter on Human and Peoples' Rights (Ratification and Enforcement) Act, above n. 65, Art. 1.

98 Ibid., preamble.

99 Sanni Abacha and Others v. Gani Fawehinmi (2001) AHLRR 172, [2002] 3 LRC 296 (Supreme Court of Nigeria, 28 April 2000), Ejiwunmi JSC.

100213 UNTS 222, entered into force 3 September 1953.

101 See, e.g., Bills of Rights in the following Constitutions: Nigeria Constitution (1960); Uganda Constitution (1962); Kenya Constitution (1969).

102 See, e.g., Ephraim v. Pastory, Civil Appeal No. 70 of 1989, (2001) AHRLR 236 (High Court of Tanzania at Mwanza, 22 February 1990), para. 10; Kachingwe and Others v. Minister of Home Affairs and Another [2005] ZWSC 134, (2005) AHRLR 288 (Zimbabwe Supreme Court, 18 July 2005) paras. $50-72$.

103 Constitution of Kenya (2010), Art. 21(3); Constitution of Zimbabwe (2013), Arts. 63-65, 71-75, and 80-83; Constitution of Mozambique (2004), Arts. 82-95; Constitution of the Republic of Seychelles (1993), Arts. 26-39; Constitution of Malawi (1994), sect. 30.

104 See generally Kangaude (2017).
} 
school girls and women in higher education against discrimination in education ${ }^{105}$; protection of individuals from sterilization on account of their Human Immunodeficiency Virus (HIV) positive status (by way of a surgical procedure or operation known as bilateral tubal ligation) without informed consent ${ }^{106}$; and the right to maternal, child and reproductive health by awarding damages due to the failure to provide pregnant women with 'the timely, immediate and emergency obstetric care'. ${ }^{107}$ Despite these developments, most domestic courts in Africa do not always take into account the ICESCR when interpreting and applying domestic law. For example, the Constitution of the Kingdom of Swaziland 2005 in section 29(6) of the Constitution protects the right to free primary education by providing that:

Every Swazi child shall within three years of the commencement of this Constitution have the right to free education in public schools at least up to the end of primary school, beginning with the first grade.

The Supreme Court of Swaziland, contrary to the ICESCR, ${ }^{108}$ held that the right to education including primary education could only be progressively realised subject to the availability of resources. ${ }^{109}$ Thus schools continued to levy compulsory parental contribution (indirect costs) for primary education, such as payment for school uniforms, which restrict access to primary education for children from families with high levels of poverty, particularly for girls.

However, some domestic courts in Africa have relied on provisions of the ICESCR and other regional and international human rights instruments ${ }^{110}$ to

\footnotetext{
105 See, e.g., Head of Department, Department of Education, Free State Province v. Welkom High School and Another; Head of Department, Department of Education, Free State Province v. Harmony High School and Another (CCT 103/12), [2013] ZACC 25, (Constitutional Court of South Africa, 10 July 2013), http://www.saflii.org/za/cases/ZACC/2013/25.html; Student Representative Council of Molepolole College of Education v. Attorney General [1995] (3) LRC 447 (Botswana Court of Appeal, 31 January 1995); Lloyd Chaduka and Morgenster College v. Enita Mandizvidza, Judgment No. SC 114/2001, Civil Appeal No. 298/2000 (Zimbabwe Supreme Court).

106 Government of the Republic of Namibia v. LM and Others (SA 49/2012), [2014] NASC 19 (3 November 2014), http://www.saflii.org/na/cases/NASC/2014/19.html; Legal and Ethical Network on HIV \& AIDS (KELIN) \& 3 Others v. Cabinet Secretary Ministry of Health \& 4 Others, Petition No. 250 of 2015, [2016] eKLR (High Court of Kenya at Nairobi, 7 December 2016), http://kenyalaw.org/caselaw/ cases/view/132167/.

107 See, e.g., The Center for Health Human Rights and Development and 4 Others v. Nakaseke District Local Administration, Civil Suit No. 111 of 2012 (High Court of Uganda, Kampala, 30 April 2015).

108 The minimum core obligation of the State includes the obligation to provide primary education which is 'compulsory' and 'available free to all'. See ICESCR, Art. 13(2)(a); CESCR, General Comment 11: Plans of Action for Primary Education, UN Doc. E/C.12/1999/4 (10 May 1999) paras. 6-7; CESCR, General Comment 13: The Right to Education, UN Doc. E/C.12/1999/10 (8 December 1999) para. 57; CESCR, Concluding Observations: Cameroon, UN Doc. E/C.12/1/Add.40 (8 December 1999) paras. 27 and 47; CEDAW, Concluding Observations: Swaziland, UN Doc. CEDAW/C/SWZ/CO/1-2 (24 July 2014) paras. 30-31.

109 Swaziland National Ex-Miners Workers Association v. The Minister of Education \& Others, Civil Appeal Case No. 2/10, [2010] SZSC 35 (Supreme Court of Swaziland, 28 May 2010), http://www. swazilii.org/sz/judgment/supreme-court/2010/35, paras. 16-21.

110 Universal Declaration of Human Rights, UN Doc. A/810 at 71 (1948), Art. 26; Convention on the Rights of the Child, 28 ILM 1456 (1989), 1577 UNTS 3, Art. 28(1)(a) and (b) and 29(1); African Charter, above n. 13, Art. 17; African Charter on the Rights and Welfare of the Child, OAU Doc. CAB/LEG/24.9/ 49 (1990), Art. 11(2) and (3).
} 
interpret and apply relevant domestic law even before ratification of the ICESCR. ${ }^{111}$ For example, the Covenant has specifically been referred to as a source of interpretation in court judgments in Kenya 'for the purpose of removing ambiguity or uncertainty from national constitutions, legislation or common law'. ${ }^{112}$ This general approach involving the use of international treaties to interpret ambiguous domestic law has also been used by other domestic courts in Africa. Thus, in August 2015 the Supreme Court of Uganda relied on the Convention on the Elimination of All Forms of Discrimination against Women $^{113}$ to interpret Article 33(6) of Uganda's Constitution 1995 which prohibit 'laws, cultures, customs or traditions which are against the dignity, welfare or interest of women or which undermine their status'. ${ }^{114}$

It is particularly instructive to note that domestic courts in South Africa and Kenya have adjudicated significant cases on ESC rights. As such, they provide good African examples on the influence of the ICESCR in Africa. Although South Africa ratified the ICESCR on 12 January 2015, it signed the Covenant on 3 October 1994. As a signatory for nearly 21 years (before ratification), its obligation to 'refrain from acts which would defeat the object and purpose of a treaty ${ }^{115}$ influenced the protection of human rights in the South African Constitution 1996, which entrenches both civil and political rights and ESC rights (e.g. right of 'everyone' to have access to adequate housing ${ }^{116}$; access to health care services, sufficient food and water and social security ${ }^{117}$; and right to education ${ }^{118}$ ) as inter-related and mutually supporting'. ${ }^{119}$ The Constitution contains two important international lawfriendly interpretive provisions. First, it provides that, in interpreting the bill of rights, courts or tribunals 'must consider international law'. ${ }^{120}$ While this provision

\footnotetext{
111 See, e.g., Governing Body of the Juma Musjid Primary School \& Others v. Essay NO \& Others (Centre for Child Law \& Another as Amici Curiae) [2011] ZACC 13, 2011 (8) BCLR 761 (CC), paras. 40-43; Attorney General v. Unity Dow (2001) AHRLR 99 (Court of Appeal, Botswana, 3 July1992), paras. 106-109, referred to Universal Declaration of Human Rights, Art. 2 and African Charter, above n. 13, Art. 2.

112 See, e.g., Republic v. Minister for Home Affairs \& 2 Others Ex Parte Sitamze, Misc Civil Case No. 1652 of 2004, [2008] eKLR, (High Court of Kenya at Nairobi, 18 April 2008), http://kenyalaw.org/ Downloads_FreeCases/2007_Immigration_decision.pdf. The Court extensively relied on the ICESCR, Arts. 6 and 2, to interpret the right of a non-national to work in Kenya. See also Mary Rono v. Jane and William Rono, Civil Appeal No. 66 of 2002, (2005) AHRLR 107 (Court of Appeal at Eldoret, 29 April 2005), paras. 19-24.

113 UN Doc. A/34/46; 1249 UNTS 13; 19 ILM 33 (1980), Arts. 2(f), 16(1)(b) and (c).

114 See Mifumi $(U)$ ltd and Others v. Attorney General and Kenneth Kakuru, Constitutional Appeal No. 02 of 2014, (Supreme Court of Uganda, Judgment of Hon Dr Esther Kisaakye, JSC, 6 August 2015) noting on pp. 59-60 of the typed judgment that: 'Uganda is a signatory [State party] to all major human rights Conventions [including the ICESCR] which require it to put in place laws and measures that prevent discrimination and perpetuate inequality'.

115 Vienna Convention on the Law of Treaties, above n. 70, Art. 18.

116 Constitution of the Republic of South Africa (1996), sect. 26.

117 Ibid., sect. 27.

118 Ibid., sect. 29.

119 See Government of the Republic of South Africa \& Others v. Grootboom \& Others [2000] ZACC 19, 2001 (1) SA 46 (CC), para. 23.

${ }^{120}$ Constitution of the Republic of South Africa (1996), sect. 39(1)(b), emphasis added.
} 
indicates possibilities open to South African courts to use international law (treaties and jurisprudence of relevant international tribunals/bodies), the obligation, not a choice, is to simply 'consider' and not to apply international law. Second, the Constitution provides that 'when interpreting any legislation, every court must prefer any reasonable interpretation of the legislation that is consistent with international law over any alternative interpretation that is inconsistent with international law'. ${ }^{121}$ This applies to interpretation of 'any legislation' even in the absence of any ambiguity. On the basis of the relevant constitutional provisions, the South African Constitutional Court has developed useful jurisprudence on the justiciability of ESC rights (based on the model of reasonableness review) with particular reference to the rights of access to health care, adequate housing, water, electricity, basic sanitation and education. ${ }^{122}$

It is evident from the Court's jurisprudence that the Constitution has been interpreted as imposing 'at very least a negative obligation [...] upon the State and all other entities and persons to desist from preventing or impairing the right of access' to ESC rights such as access to adequate housing ${ }^{123}$ or right to a basic education $^{124}$; and positive State obligations to protect and fulfil ESC rights. The constitutional positive obligations imposed upon government with respect to ESC rights will be enforced by courts in at least the following ways: First, if the government fails to take steps to ensure that ESC rights are progressively realised, 'the courts will require government to take steps'. ${ }^{125}$ Second, if steps or measures taken by the government are unreasonable (e.g. by failing to provide for those most desperately in need), the courts will 'require that they be reviewed so as to meet the constitutional standard of reasonableness'. ${ }^{126}$ Third, if government adopts a policy with unreasonable limitations or exclusions, the court may order that those unreasonable limitations or exclusions 'are removed'. ${ }^{127}$

While the Court's jurisprudence shows how the State and specific aspects of public policy can be held accountable for failure to respect, protect and fulfil ESC rights via a constitutional culture of justification and accountability through litigation, it has signalled that the Court does not intend to adopt and apply the notion developed by the CESCR that ESC rights contained a minimum core (or

\footnotetext{
121 Ibid., sect. 233.

122 See, e.g., Thiagraj Soobramoney v. Minister of Health, KwaZulu-Natal 1998 (1) SA 765 (CC), 1997 (12) BCLR 1696 (CC) (Soobramoney); Government of the Republic of South Africa and Others $v$. Grootboom and Others 2001 (1) SA 46 (CC), 2000 (11) BCLR 1169 (CC) (Grootboom); Minister of Health and Others v. Treatment Action Campaign 2002 (5) SA 721 (CC), 2002 (10) BCLR 1033 (CC) (Treatment Action Campaign ); Khosa and Others v. Minister of Social Development 2004 (6) SA 505 (CC), 2004 (6) BCLR 569 (CC) (Khosa); Abahlali Basemjondolo Movement SA and Another v. Premier of the Province of Kwazulu-Natal and Others (CCT12/09), [2009] ZACC 31, 2010 (2) BCLR 99 (CC); Mazibuko and Others v. City of Johannesburg and Others (CCT 39/09), [2009] ZACC 28, 2010 (3) BCLR 239 (CC); City of Johannesburg Metropolitan Municipality v. Blue Moonlight Properties 39 (Pty) Ltd and Another (CC) [2011] ZACC 33, 2012 (2) BCLR 150 (CC); and Juma Musjid, above n. 111.

123 Grootboom, above n. 122, para. 34.

124 Juma Musjid, above n. 111, para. 58.

125 Mazibuko and Others v. City of Johannesburg and Others (CCT 39/09), [2009] ZACC 28, para. 67.

126 Ibid.

127 Ibid.
} 
'minimum essential levels') which the State is obliged to ensure. ${ }^{128}$ The Committee's minimum core approach, recently reaffirmed in two General Comments adopted in March 2016, ${ }^{129}$ has thus not been applied by the South African Constitutional Court. Instead the Court has preferred a high level of deference to the legislature and executive. In Grootboom and Treatment Action Campaign, the South African Constitutional Court explicitly rejected the argument based on the CESCR General Comments 3 and 14 that ESC rights protected under sections 26-27 of the South African Constitution 1996 (right to have 'access' to adequate housing; healthcare; sufficient food and water; and social security) imposed a minimum core obligation on the State. The Court held that sections 26 and 27 did not entitle anyone to the direct provision of minimum essential levels of the relevant goods and services from the State. ${ }^{130}$ According to the Court:

It is impossible to give everyone access even to a 'core' service immediately. All that is possible, and all that can be expected of the state, is that it act[s] reasonably to provide access to the socio-economic rights identified in sections 26 and 27 on a progressive basis. ${ }^{131}$

Thus in Mazibuko case, the applicants alleged, inter alia, that a Free Basic Water policy to supply 6 kilolitres of free water per month to every account holder (regardless of household size) in the City of Johannesburg violated the right to have access to 'sufficient water' under sections 27 of the South African Constitution 1996. ${ }^{132}$ The Constitutional Court had to consider whether the City of Johannesburg's Free Basic Water policy was 'reasonable' in terms of section 27(1)(b) of the Constitution, which guarantees everyone's right of access to sufficient water. The applicants contended, inter alia, that the Court should determine a quantified amount of water as 'sufficient water' within the meaning of section 27 of the Constitution and that this amount is 50 litres per person per day. ${ }^{133}$ The Court (contrary to judgments in the High

\footnotetext{
128 CESCR, General Comment 3, above n. 56, para. 10: '...Committee is of the view that a minimum core obligation to ensure the satisfaction of, at the very least, minimum essential levels of each of the rights is incumbent upon every State party. Thus, for example, a State party in which any significant number of individuals is deprived of essential foodstuffs, of essential primary health care, of basic shelter and housing, or of the most basic forms of education is, prima facie, failing to discharge its obligations under the Covenant...'.

129 CESCR, General Comment 22, above n. 76, para. 49; and CESCR, General Comment 23, above n. 97, para. 65 .

130 Grootboom, above n. 122, paras. 23-33; Treatment Action Campaign, above n. 122, paras. 26-39.

131 Treatment Action Campaign, above n. 122, para. 35.

132 Sect. 27 provides: '(1) Everyone has the right to have access to -

(a) health care services, including reproductive health care;

(b) sufficient food and water; and

(c) social security, including, if they are unable to support themselves and their dependents, appropriate social assistance.

(2) The state must take reasonable legislative and other measures, within its available resources, to achieve the progressive realisation of each of these rights.

(3) No one may be refused emergency medical treatment'.

133 Mazibuko and Others v. City of Johannesburg and Others (CCT 39/09), [2009] ZACC 28, paras. 44(a) and 51.
} 
Court ${ }^{134}$ and Supreme Court of Appeal ${ }^{135}$ ) refrained from defining the minimum core content of the right of access to 'sufficient water' under section 27(1)(b) of the Constitution and held that the 'applicants have not persuaded this Court to specify what quantity of water is "sufficient water" within the meaning of section 27 of the Constitution'. ${ }^{136}$ According to the Court the right to 'sufficient water' does not require the State upon demand to provide every person with sufficient water without more but rather 'it requires the state to take reasonable legislative and other measures progressively to realise the achievement of the right of access to sufficient water, within available resources'. ${ }^{137}$ Without giving contextual meaning to the constitutional standard of 'reasonableness' and the minimum core content of the right to 'sufficient water', the Court found the City's Free Basic Water policy to fall 'within the bounds of reasonableness'. According to the Court:

ordinarily it is institutionally inappropriate for a court to determine precisely what the achievement of any particular social and economic right entails and what steps government should take to ensure the progressive realisation of the right. This is a matter, in the first place, for the legislature and executive, the institutions of government best placed to investigate social conditions in the light of available budgets and to determine what targets are achievable in relation to social and economic rights. Indeed, it is desirable as a matter of democratic accountability that they should do so for it is their programmes and promises that are subjected to democratic popular choice. ${ }^{138}$

Therefore, the 'reasonableness' review for assessing State compliance with ESC rights obligations has been applied to allow the government a wide margin of discretion to, inter alia, determine 'what the achievement of any particular social and economic right entails'. Consequently, the normative content core content of the right to 'sufficient water' remained ambiguous. This means that there is no clear guidance regarding State obligations and entitlements for individuals and groups.

The influence of the ICESCR in South African can also be discerned from the constitutional protection of the right to education and how this right has been enforced by courts. In 2011 (before ratification of the ICESCR by South Africa on 18 January 2015, which entered into force for South Africa on 12 April 2015) in the case of Juma Musjid ${ }^{139}$ the Constitutional Court of South Africa relied on Articles 13 and 14 of the ICESCR to interpret and apply section 29(1)(a) of the Constitution of South Africa protecting the right to education as follows:

Everyone has the right -

(a) to a basic education, including adult basic education; and

134 Mazibuko and Others $v$. City of Johannesburg and Others (06/13865), [2008] 4 All SA 471, (W) (30 April 2008), Tsoka $\mathrm{J}$ (holding that a basic minimum of 50 litres per person per day should be provided).

135 City of Johannesburg and Others v. Mazibuko and Others (489/08), [2009] 3 All SA 202 (SCA) (25 March 2009) (holding that a basic minimum of 42 litres per person per day should be provided).

136 Mazibuko and Others v. City of Johannesburg and Others (CCT 39/09), [2009] ZACC 28, para. 159.

137 Ibid., para. 50.

138 Ibid., para. 61, O’Regan J.

139 Juma Musjid, above n. 111. 
(b) to further education, which the state, through reasonable measures, must make progressively available and accessible. ${ }^{140}$

The Court held that unlike some of the other 'socio-economic rights' under the South African Constitution, ${ }^{141}$ the right to a basic education under Article $29(1)(a)$ is 'immediately realisable' since there is no internal limitation requiring that the right be 'progressively realised' within 'available resources' subject to 'reasonable legislative measures'. ${ }^{142}$ The Court distinguished the right to a 'basic education' from the right to 'further education' provided for in section 29(1)(b), which oblige the State through reasonable measures, to make further education 'progressively available and accessible'. ${ }^{143}$ The Court further relied on CESCR General Comment 13 to stress the importance of the right to education ${ }^{144}$ and concluded that:

Indeed, basic education is an important socio-economic right directed, among other things, at promoting and developing a child's personality, talents and mental and physical abilities to his or her fullest potential. ${ }^{[145]}$ Basic education also provides a foundation for a child's lifetime learning and work opportunities. To this end, access to school—an important component of the right to a basic education guaranteed to everyone by section 29(1)(a) of the Constitution - is a necessary condition for the achievement of this right. ${ }^{146}$

The South African example of constitutional protection of justiciable ESC rights and judicial enforcement of these rights has been followed in other African States in particular in Kenya. ${ }^{147}$ It also demonstrated that judicial or quasi-judicial bodies can consider and determine claims submitted by or on behalf of individuals or groups of individuals, claiming to be victims of a violation of any of the ESC right protected in the ICESCR. This partly influenced the adoption of the Optional Protocol to the ICESCR which provides for the competence of the Committee on Economic, Social and Cultural Rights to receive and consider communications by or on behalf of individuals or groups of individuals. This would in turn contribute to the development of international jurisprudence on ESC rights.

\footnotetext{
${ }^{140}$ Constitution of the Republic of South Africa (1996), sect. 29(1).

141 Ibid., Arts. 26(1) and 27. The right to have access to adequate housing under sect. 26(1) of the Constitution and the right to have access to health care services, sufficient food and water, and social security under sect. 27 of the Constitution. These rights are subject to an internal limitation that the State must take reasonable legislative measures, within its available resources, to achieve the progressive realisation of the right.

142 Juma Musjid, above n. 111, para. 37. See also Minister of Basic Education v. Basic Education for All (20793/2014), [2015] ZASCA 198 (Supreme Court of Appeal, 2 December 2015).

143 Juma Musjid, above n. 111, para. 37.

144 CESCR, General Comment 13: The Right to Education, UN Doc. E/C.12/1999/10 (8 December 1999) para. 1.

145 The court cited the Convention on the Rights of the Child, Art. 29(1).

146 Juma Musjid, above n. 111, para. 43.

147 See Constitution of Kenya (2010), Arts. 43-44, 53. Under Art. 165(3)(b) the High Court is empowered to 'determine the question whether a right or fundamental freedom in the Bill of Rights has been denied, violated, infringed or threatened'.
} 
Influenced by the ICESCR, the Constitution of Kenya 2010 protected what used to be considered solely as 'needs' and 'services' as fully justiciable entitlements at par with civil and political rights. ${ }^{148}$ The Constitution guarantees every person a right to the highest attainable standard of health, accessible and adequate housing, reasonable standards of sanitation, freedom from hunger, adequate food of acceptable quality, clean and safe water in adequate quantities, social security and education. ${ }^{149}$ The State is obliged to 'observe, respect, protect, promote and fulfil' all rights in the Bill of Rights and to 'take legislative, policy and other measures, including the setting of standards, to achieve the progressive realisation of the rights guaranteed under Article 43, ${ }^{150}$ subject to available resources. ${ }^{151}$ This provides a strong legal basis for courts to consider whether the measures or policies taken by the State or any State organ, if any, with respect to ESC rights (e.g. access to healthcare, housing, food, water and sanitation) meet the constitutional standards. ${ }^{152}$ In several cases the High Court has applied the standard of whether or not policies or measures in issue are 'reasonable in the circumstances' ${ }^{153}$ Since the adoption of Kenya's 2010 Constitution, domestic courts in Kenya have increasingly relied directly on the ICESCR and General Comments of the CESCR to interpret ESC rights protected in Kenya's Constitution. ${ }^{154}$ For example, the Court has relied directly on Article 12 ICESCR and the CESCR General Comment 14 (on the right to health) and General Comment 17 (on the right of Everyone to benefit from the protection of the moral and material interests resulting from any scientific,

\footnotetext{
148 Michael Mutinda Mutemi v. Permanent Secretary, Ministry of Education \& 2 Others, Petition No. 133 of 2013, [2013] eKLR (High Court of Kenya at Nairobi, 1 November 2013), http://kenyalaw.org/ caselaw/cases/view/91830/, para. 13.

149 Constitution of Kenya (2010), Art. 43.

150 Ibid., Arts. 21(1) and (2). In Mitu-Bell Welfare Society v. Attorney General \& 2 Others, Petition No. 164 of 2011, [2013] eKLR (High Court of Kenya at Nairobi, 11 April 2013), http://kenyalaw.org/caselaw/ cases/view/87948, para. 53. Judge Mumbi Ngugi held that 'progressive realisation' implies that 'the state must begin to take steps, and I might add be seen to take steps, towards realization of these rights', emphasis in the original.

151 Constitution of Kenya (2010), Art. 43(5); ICESCR, above n. 1, Art. 2(1).

152 See, e.g., Mathew Okwanda v. Minister of Health and Medical Services \& 3 Others, Petition No. 94 of 2012, [2013] eKLR (High Court of Kenya at Nairobi, 17 May 2013), http://kenyalaw.org/caselaw/ cases/view/88803, para. 24; Kenya Society for the Mentally Handicapped v. Attorney General and 7 Others, Petition No. 155A of 2011, [2012] eKLR (High Court of Kenya at Nairobi, 18 December 2012), http://kenyalaw.org/caselaw/cases/view/86061, para. 18.

153 See, e.g., Luco Njagi \& 21 Others v. Ministry of Health \& 2 Others, Petition No. 218 of 2013, [2015] eKLR (High Court of Kenya at Nairobi, 28 January 2015), http://kenyalaw.org/caselaw/cases/view/ $105546 /$, paras. 85 and 90 concluding that 'the measures taken by the respondents to ensure access to haemodialysis by the petitioner are reasonable in the circumstances' due to limited available resources. See also Consumer Federation of Kenya (COFEK) v. Attorney General \& 4 Others, Petition No. 88 of 2011, [2012] eKLR, http://kenyalaw.org/caselaw/cases/view/82947, para. 39.

154 See, e.g., John Kabui Mwai \& 3 Others v. Kenya National Examination Council \& 2 Others, Petition No. 15 of 2011, [2011] eKLR (High Court of Kenya at Nairobi, 16 September 2011), http://kenyalaw.org/ Downloads_FreeCases/83548.pdf, 6-7, the Court directly relied on Arts. 13 and 14 of the ICESCR after observing that under Art. 2(6) of Kenya's Constitution (2010) the ICESCR 'forms part of our [Kenya] laws' since Kenya is a State party to the Covenant. See also P.A.O. \& 2 Others v. Attorney General, Petition No. 409 of 2009, [2012] eKLR (High Court of Kenya at Nairobi, 20 April 2012), http://kenyalaw. org/Downloads_FreeCases/85611.pdf, paras. 58-64, 86; Luco Njagi, above n. 153, paras. 63-64.
} 
literary or artistic production of which he or she is the author) to interpret the scope of the right to health in Kenya. ${ }^{155}$

\subsection{Monist Approach to the ICESCR in Africa and Influence on Human Rights}

Monism emphasises that national and international law form one single legal order, or at least a number of interlocking orders which should be presumed to be coherent and consistent. ${ }^{156}$ Accordingly in States applying monism to international treaties, a treaty such as the ICESCR may, without legislation, become part of domestic law and can be applied directly within the national legal order once it has been concluded in accordance with the constitution and has entered into force for the State. ${ }^{157}$ Nevertheless, in practice, legal institutions of a 'monist' State, such as its legislature and judiciary, should ensure that national law conforms to international law and that international law can be relied on in national courts. In cases of conflict, national courts should give effect to international law. In 'monist' African States (following the civil law tradition based on the Constitution of France 1958) ${ }^{158}$ international treaties in force for the State can be applied directly within the national legal order, without legislation. Some constitutions of a number of 'Francophone'159 and 'Lusophone'160 African States expressly provide (in the Preamble or other parts of the Constitution) that duly signed and ratified treaties in accordance with constitutional processes are part of or take precedence over national legislation, or that human rights protected in the Constitution shall be interpreted in harmony with the relevant international instruments. ${ }^{161}$ Treaties in such States are, in theory, superior to (supersede) ordinary legislation but subject to

\footnotetext{
155 Patricia Asero Ochieng and 2 Others v. The Attorney General \& AIDS Law Project, Petition No. 409 of 2009 (High Court of Kenya at Nairobi, 20 April 2012), paras. 57-64.

156 Crawford (2012), p. 48.

157 Aust (2013), p. 163.

158 The Constitution of France (1958), Art. 55: 'Treaties or agreements duly ratified or approved shall, upon publication, prevail over Acts of Parliament, subject, with respect to each agreement or treaty, to its application by the other party'.

159 See Constitutions of the following former French colonies in Africa: Algeria (1989), Art. 132; Benin (1990) preamble and Art. 147; Burkina Faso (1991), preamble; Burundi (2004), Art. 292; Cameroon (1996), Art. 45; Central African Republic (1995), preamble; Chad (1996), preamble and Art. 221; DRC (2005), Art. 215; Congo (2001), Art. 184; Guinea (1990), preamble; Madagascar (1992), preamble; Mali (1992), preamble and Art. 116; Niger (1999), preamble and Art. 132; Rwanda, Art. 190; Senegal (2001), Art. 98; Seychelles (1993), Art. 48; Togo (1992), preamble; and Tunisia (2014), Art. 20.

160 See Constitutions of the following six former colonies of the Portuguese Empire in Africa: Angola (2010), Art. 13; Cape Verde (1992), Art. 11; Guinea-Bissau (1984), Art. 28; Mozambique (2004), Art. 18; São Tomé and Príncipe (1975), Arts. 12 and 17 and Equatorial Guinea (1991), preamble and Art. 14.

161 See, e.g., Constitution of São Tomé and Príncipe (1975), Arts. 12 and 17; Equatorial Guinea (1991), preamble and Art. 14; Guinea-Bissau (1984), Art. 28; and Constitution of Mozambique (2004), Art. 43: 'The constitutional principles in respect of fundamental rights shall be interpreted and integrated in harmony with the Universal Declaration of Human Rights and with the African Charter of Human and Peoples' Rights'.
} 
the Constitution. ${ }^{162}$ However, in practice 'monist' States in Africa require international treaties to be officially published before becoming part of domestic law. ${ }^{163}$ Courts may also need to determine the extent to which rights protected by the ICESCR are 'justiciable' or 'self-executing', that is may be directly applied by courts without further specification or definition by the legislature. Thus, enforcement of the ICESCR in 'monist' African States may require a State to 'take prior legislative measures' to make provisions of the ICESCR applicable in domestic law. ${ }^{164}$ It must be acknowledged that generally most courts in 'monist' African States have not given full effect to the provisions of the ICESCR in the domestic legal order, especially by providing for judicial and other remedies for violations of ESC rights. ${ }^{165}$ As a result, the influence of the ICESCR on domestic legislation, policies and national courts jurisprudence in most 'monist' African States has been very limited partly because historically judicial training has not paid adequate attention to international human rights including the justiciability of ESC rights. ${ }^{166}$ In this context, the ICESCR has not been used as a source of directly enforceable rights or a source of inspiration in the interpretation of relevant domestic law in court judgments as judges tend to rely on domestic legislation (which is inadequate to implement the rights guaranteed under the ICESCR) with which they are more familiar. ${ }^{167}$ Therefore, it is imperative to ensure that national human rights institutions do not concentrate solely on civil and political rights, but accord equal weight and attention to ESC rights.

For example, the Constitution of Rwanda 2003 protects several ESC rights including rights to free choice of employment, equal pay for equal work, form trade unions, strike, education and health. ${ }^{168}$ It further provides that international treaties and agreements have precedence over domestic laws ${ }^{169}$ and thus can be applied

\footnotetext{
162 See, e.g., Constitution of Central African Republic (2013), Art. 97: 'Agreements or Treaties properly ratified or approved, take precedence, once published, over laws, on the condition, for each Agreement or Treaty, of its application by the other parties'. See also Constitution of Cape Verde (1992), Art. 11 and Constitution of Tunisia (2014), Art. 20.

163 See, e.g., Constitution of Senegal (2001), Art. 98: 'Treaties or agreements duly ratified shall, upon their publication, have an authority superior to that of the laws, subject, for each treaty and agreement, to its application by the other party' (emphasis added). See also Constitutions of Angola (2010), Art. 13(1) and Benin (1990), Art. 147.

164 See Souleymane Guengueng and Others v. Hissène Habré (2002) AHRLR 183, para. 38 (Senegal Court of Cassation, 20 March 2001).

165 See Cateme Community v. State of Mozambique, Judgment No. 15/TAPT/14, Process No. 04/2014, the Administrative Court of Tete Province, 4 June 2014; CESCR, Concluding Observations: Democratic Republic of the Congo, UN Doc. E/C.12/COD/CO/4 (16 December 2009) para. 8; Tunisia, UN Doc. E/C.12/TUN/CO/3 (14 November 2016) para. 6.

166 USAID (2013), p. 28.

167 See, e.g., Case No. 501 of 27 July 1984, Dakar Court of Appeal, Senegal. Although the case raised an issue concerning the right of access to good quality public health facilities, it was determined on the basis of relevant domestic law (Art. 142 of the Code of the Obligations of the Administration, Act No. 65-61 of 19 July 1965) without any reference to Art. 12 ICESCR.

168 Constitution of the Republic of Rwanda (2003), Arts. 37-41.

169 Ibid., Art. 190 provides: 'Upon their publication in the official gazette, international treaties and agreements which have been conclusively adopted in accordance with the provisions of law shall be more binding than organic laws and ordinary laws except in the case of non-compliance by one of the parties'.
} 
directly in the domestic legal order. In addition, it reaffirms 'adherence to the principles of human rights' enshrined in various treaties, namely:

the United Nations Charter of 26 June 1945, the Convention on the Prevention and Punishment of the crime of Genocide of 9 December 1948, the Universal Declaration of Human Rights of 10 December 1948, the International Convention on the Elimination of All Forms of Racial Discrimination of 21 December 1965, the International Covenant on Civil and Political Rights of 19 December 1966, the International Covenant on Economic, Social and Cultural Rights of 19 December 1966, the Convention on the Elimination of all Forms of Discrimination against Women of 1 May 1980, the African Charter of Human and Peoples' Rights of 27 June 1981 and the Convention on the Rights of the Child of 20 November $1989 .{ }^{170}$

However, the influence of the ICESCR in Rwanda has been limited by the absence of cases of invocation before, or direct or indirect application of the Covenant by, domestic courts or tribunals. ${ }^{171}$ This is also true in other in African States giving primacy to international treaties, or making ratified international treaties part of domestic law, ${ }^{172}$ or providing that the Bill of Rights 'shall be interpreted in such a way as not to be inconsistent with any international obligations ${ }^{173}$ including human rights obligations under the ICESCR.

For example, Article 132 of the Constitution of the People's Democratic Republic of Algeria 1989 (amended by the constitutional revision of 1996) ${ }^{174}$ provides: 'Treaties ratified by the President of the Republic in accordance with the conditions provided for by the Constitution are superior to [national] law'. Despite the superiority of the Covenant in Algeria, in 2010 the CESCR was concerned that there was 'an absence of jurisprudence invoking the Covenant provisions, despite the primacy of the Covenant over national law established by article 132 of the Constitution'. ${ }^{175}$ The Committee recommended that Algeria 'take effective measures to increase awareness of Covenant rights among the judiciary and the public at large, and to ensure that judicial training take full account of the justiciability of Covenant rights' ${ }^{176}$ To date jurisprudence invoking the ICESCR is still non-existent.

\footnotetext{
170 Ibid., preamble para. 9 (emphasis added).

171 CESCR, Concluding Observations: Rwanda, UN Doc. E/C.12/RWA/CO/2-4 (10 June 2013) para. 6.

172 See, e.g., Constitution of the Federal Democratic Republic of Ethiopia (1994), Art. 9(4), which provides: 'All international agreements ratified by Ethiopia are an integral part of the law of the land'. See also the Constitution of the Republic of Namibia (1990, as amended), Art. 144; CESCR, Concluding Observations: Ethiopia, UN Doc. E/C.12/ETH/CO/1-3 (31 May 2012) para. 5.

173 Constitution of the Republic of Seychelles (approved on 18 June 1993, amended by Act No. 14 of 1996), Art. 48. Seychelles acceded to the ICESCR on 5 May 1992 but had not submitted even a single report to the CESCR by June 2016, more than 23 years after accession.

174 Constitution of the People's Democratic Republic of Algeria (adopted on 28 November 1996, amended in 2002 and 2008), http://www.algerianembassy.org.uk/index.php/constitution.html.

175 CESCR, Concluding Observations: Algeria, UN Doc. E/C.12/DZA/CO/4 (7 June 2010) para. 5. 176 Ibid.
} 
The observation above (failure to the invoke the ICESCR before or apply it by national courts) and the recommendation above (direct applicability of the ICESCR by promoting it, inter alia, among judges and the general population at large) appear in several other CESCR concluding observations on African State reports, ${ }^{177}$ as most recently exemplified by the following observations with respect to Burundi:

5. The Committee finds it regrettable that, despite the constitutional standing of the Covenant, its provisions have never been invoked before or applied by national courts.

6. The Committee recommends that the State party ensure the direct applicability of the Covenant by promoting among judges, attorneys, public officials and other officials responsible for application of the Covenant, as well as among rights holders, an awareness of the content of the Covenant and of the possibility of invoking it in the justice system... ${ }^{178}$

It follows from the foregoing that constitutional provisions providing for the direct applicability of the ICESCR do not necessarily give rise to the application of the Covenant by national courts and tribunals. States should take measure (such as specialised training for judges, magistrates and parliamentarians) to promote the domestic implementation of the Covenant by national authorities. In addition, NGOs should pursue cases involving systematic violations of ESC rights in the public interest in order to protect the underprivileged and marginalised populations in society. This will help national courts to apply the ICESCR in interpreting domestic law in order to develop the content of ESC rights and to define the nature of obligations of both States and non-State actors. ${ }^{179}$

\section{Conclusion}

The ICESCR has significantly influenced the regional and, to some extent, domestic legal protection of ESC rights in Africa. As noted above, the Covenant influenced the explicit protection of ESC rights in the African Charter and in several constitutions in Africa. While there is no consistent practice among African States, there is an increasing trend towards more constitutional protection of many ESC rights in Africa either as justiciable human rights or at least as 'directive principles' of State policy. Nevertheless, ESC rights have still not attained the same level of protection extended to civil and political rights in the constitutions of many African

\footnotetext{
177 See, e.g., CESCR, Concluding Observations: Angola, UN Doc. E/C.12/AGO/CO/3 (1 December 2008) para. 9; Benin, E/C.12/BEN/CO/2 (9 June 2008) paras. 9 and 30; Chad, UN Doc. E/C.12/TCD/CO/ 3 (16 December 2009) para. 9; Ethiopia, UN Doc. E/C.12/ETH/CO/1-3 (31 May 2012) para. 5; Morocco, UN Doc. E/C.12/MAR/CO/4 (22 October 2015) paras. 9-10; Sudan, UN Doc. E/C.12/SDN/CO/2 (27 October 15) paras. 5-6; Rwanda, UN Doc. E/C.12/RWA/CO/2-4 (10 June 13) para. 6; Tunisia, UN Doc. E/C.12/TUN/CO/3 (7 October 2016) paras. 7-8; Uganda, UN Doc. E/C.12/UGA/CO/1 (24 June 2015) para. 5.

178 CESCR, Concluding Observations: Burundi, UN Doc. E/C.12/BDI/CO/1 (16 October 2015) paras. 5-6. See also CESCR, Concluding Observations: Chad, UN Doc. E/C.12/TCD/CO/3 (16 December 2009) para. 7.

${ }^{179}$ Kapindu (2013), pp. 125-151.
} 
States. Besides, the influence of the Covenant on national courts' jurisprudence in most African States remains limited. There are still several factors limiting the realisation of ESC rights in Africa including non-compliance with domestic court rulings in favour of ESC rights, ${ }^{180}$ political authoritarianism, high levels of corruption, ${ }^{181}$ poverty, ${ }^{182}$ armed conflicts, limited engagement of NGOs and civil society as well as lack of respect for the rule of law ${ }^{183}$ including lack of respect for international and regional (quasi-) judicial bodies, ${ }^{184}$ as reflected in African States non-compliance with the recommendations of the African Commission, noncompliance with the judgments and orders of the African Court, ${ }^{185}$ and noncompliance by African States (e.g. Malawi, Chad, the Democratic Republic of the Congo, Djibouti, Uganda and South Africa) with obligations under the Rome Statute of the International Criminal Court. ${ }^{186}$

\footnotetext{
180 See, e.g., Ibrahim Sangor Osman v. Minister of State for Provincial Administration and Internal Security, Constitutional Petition No. 2 of 2011, [2011] eKLR, http://kenyalaw.org/Downloads_FreeCases/ Embu_Pet_2_2011.pdf; CESCR, Concluding Observations: Kenya, E/C.12/KEN/CO/2-5 (4 March 2016) paras. 7-8.
}

181 See CESCR, Concluding Observations: Kenya, UN Doc. E/C.12/KEN/CO/2-5 (4 March 2016) paras. 17-18 and Olaniyan (2014); The Negative Impact of Corruption on the Enjoyment of Human Rights, Human Rights Council Resolution 23/9, A/HRC/RES/23/9 (20 June 2013); Preventing and Combating Corrupt Practices and the Transfer of Proceeds of Corruption, Facilitating Asset Recovery and Returning such Assets to Legitimate Owners, in particular to Countries of Origin, in accordance with the United Nations Convention against Corruption, Resolution adopted by the General Assembly on 18 December 2014, A/RES/69/199 (5 February 2015).

182 The Fund for Peace (FFP) (The Fund for Peace 2015), Fragile States Index 2015: Fragility in the World 2015, http://fsi.fundforpeace.org/rankings-2015. The Index is based on several indicators including uneven economic development, poverty and human rights.

183 See, e.g., Matia Katabazi and 21 Others v. Secretary General of the East African Community and the Attorney General of the Republic of Uganda, Reference No. 1 of 2007, http://www.saflii.org/ea/cases/ EACJ/2007/3.html; Gramara (Private) Limited and Another v. The Government of the Republic of Zimbabwe (HC33/09), [2010] ZWHHC 1 (26 January 2010); Government of the Republic of Zimbabwe v. Fick \& Others (657/11), [2012] ZASCA 122 (20 September 2012); Government of the Republic of Zimbabwe v. Fick and Others (CCT 101/12), [2013] ZACC 22 (27 June 2013).

${ }^{184}$ For example, although Uganda is a State party to the Rome Statute of the International Criminal Court, 2187 UNTS 90, on 12 May 2016 Ugandan President Yoweri Museveni during his swearing in speech extending his 30-year rule told visiting heads of State and representatives of the US and EU member States in Uganda that: 'We lost interest in the ICC [International Criminal Court]. [...] ICC is none of our business. It is a useless body. We had supported the ICC initially thinking they were serious [...] but it is a bunch of useless people'. See Clottey (2016).

185 See, e.g., Interim Report of the African Court on Human and Peoples' Rights notifying the Executive Council of Non-Compliance by a State, in accordance with Article 31 of the Protocol, http:// en.african-court.org/images/Other\%20Reports/AFCHPR_Interim_Report_Non_compliance_by_a_

State___Libya.pdf.

186 The Prosecutor v. Omar Hassan Ahmad Al Bashir, Pre-Trial Chamber I, 'Corrigendum to the Decision Pursuant to Article 87(7) of the Rome Statute on the Failure by the Republic of Malawi to Comply with the Cooperation Requests Issued by the Court with Respect to the Arrest and Surrender of Omar Hassan Ahmad Al Bashir', ICC- 02/05-01/09-139-Corr, 13 December 2011; Pre-Trial Chamber I, 'Decision pursuant to article 87(7) of the Rome Statute on the refusal of the Republic of Chad to comply with the cooperation requests issued by the Court with respect to the arrest and surrender of Omar Hassan Ahmad Al Bashir', ICC-02/05- 01/09-140-tENG, 13 December 2011; Pre-Trial Chamber II, 'Decision on the Non-compliance of the Republic of Chad with the Cooperation Requests Issued by the Court Regarding the Arrest and Surrender of Omar Hassan Ahmad Al-Bashir', ICC-02/05-01/09-151, 26 March 2013; Pre-Trial Chamber II, 'Decision on the Cooperation of the Democratic Republic of the Congo Regarding Omar Al Bashir's 
In order to enhance the influence of the ICESCR in Africa, these factors must be addressed by implementing a wider range of comprehensive, necessary, appropriate and effective legal, economic and educational measures, plans of action and policies by States, including: (i) enacting and implementing domestic legislation to give effect to the ICESCR; (ii) providing extensive training and conducting awarenessraising campaigns on the ICESCR and the justiciability of ESC rights to politicians, law makers, national and local civil servants, law enforcement officers, and students at all levels of educations; (iii) training members of all professions and sectors that have a direct role in the promotion and protection of human rights, including judges, lawyers, prosecutors, civil servants, teachers, immigration officers, the military, the police and other law enforcement officers on the domestic application of international human rights treaties including specific training programmes on the ICESCR; (iv) adopting and effectively implementing poverty reduction strategies, in cooperation with relevant (non-governmental/civil society, regional and international) organisations and institutions, which should fully integrate the ESC rights; (v) ensuring accountability and transparency in the management of public funds and in the conduct of public authorities and allocation of available resources to relevant sectors, especially those addressed to the most disadvantaged and marginalised social groups and individuals, in law and in practice; (vi) signing and ratifying, without delay the Optional Protocol to the ICESCR, which offers a complementary and accessible forum of accountability for neglected ESC rights ${ }^{187}$; (vii) increased use of strategic litigation as a means of achieving political recognition (irrespective of the outcome or implementation of the cases) to support the empowerment of marginalised individuals and groups such as indigenous peoples ${ }^{188}$; and (viii) timely submission of periodic reports to the Committee on Economic, Social and Cultural Rights including a compilation of case summaries and decisions adopted by domestic courts and tribunals on the justiciability of ESC rights.

Open Access This article is distributed under the terms of the Creative Commons Attribution 4.0 International License (http://creativecommons.org/licenses/by/4.0/), which permits unrestricted use, distribution, and reproduction in any medium, provided you give appropriate credit to the original author(s) and the source, provide a link to the Creative Commons license, and indicate if changes were made.

Footnote 186 continued

Arrest and Surrender to the Court', ICC-02/05-01/09-195, 9 April 2014; Pre-Trial Chamber II, 'Decision on the non-compliance by the Republic of Djibouti with the request to arrest and surrender Omar AlBashir to the Court and referring the matter to the United Nations Security Council and the Assembly of the State Parties to the Rome Statute', ICC-02/05-01/09-266, 11 July 2016; Pre-Trial Chamber II, 'Decision on the non-compliance by the Republic of Uganda with the request to arrest and surrender Omar Al Bashir to the Court and referring the matter to the United Nations Security Council and the Assembly of State Parties to the Rome Statute', ICC-02/05-01/09-267, 11 July 2016; Decision under Article 87(7) of the Rome Statute on the non-compliance by South Africa with the request by the Court for the arrest and surrender of Omar Al-Bashir, ICC-02/05-01/09-302, 6 July 2017.

187 See, e.g., IDG v. Spain, Communication No. 2/2014, UN Doc. E/C.12/55/D/2/2014 (13 October 2015); Miguel Ángel López Rodríguez v. Spain, Communication No. 1/2013, UN Doc. E/C.12/57/D/1/ 2013 (20 April 2016).

188 See, e.g., Gilbert (2017), p. 657. 


\section{References}

Aust A (2013) Modern treaty law and practice, 3rd edn. Cambridge University Press, Cambridge

Chitimira H (2017) An analysis of socio-economic and cultural rights protection under the Zimbabwe Constitution of 2013. J Afr Law. doi:10.1017/S0021855317000109

Clottey P (2016) International Court urges Uganda to arrest Sudan President Bashir. Voice of America, 13 May 2016. http://www.voanews.com/content/sudanese-president-bashir-defies-international-arrestwarrant-with-trip-to-uganda/3327216.html. Accessed 13 Feb 2017

Crawford J (2012) Brownlie's principles of public international law, 8th edn. Oxford University Press, Oxford

Dicey AV (1915) Introduction to the study of the law of the Constitution, 8th edn. Macmillan, London

Gilbert J (2017) Litigating indigenous peoples' rights in Africa: potentials, challenges and limitations. Int Comp Law Q 66:657-686

Goodman R, Jinks D (2003) Measuring the effects of human rights treaties. Eur J Int Law 14(1):171-183

Harris DJ, Sivakumaran S (2015) Cases and materials on international law, 8th edn. Sweet and Maxwell, London

Hathaway OA (2002) Do human rights treaties make a difference? Yale Law J 111(8):1935-2042

Heyns C, Kaguongo W (2006) Constitutional human rights law in Africa: current developments. S Afr J Hum Rights 22:673-717

Kangaude GD (2017) Legal grounds: reproductive and sexual rights in Sub-Saharan African courts, vol III. Pretoria University Law Press, Pretoria

Kapindu RE (2013) Courts and the enforcement of socio-economic rights in Malawi: jurisprudential trends, challenges and opportunities. Afr Hum Rights Law J 13:125-151

Murray R, Long D (2015) The implementation of the findings of the African Commission on Human and Peoples' Rights. Cambridge University Press, Cambridge

Olaniyan K (2014) Corruption and human rights law in Africa. Hart Publishing, Oxford

Prempeh HK (2007) Africa's 'constitutionalism revival': false start or new dawn? Int J Const Law 5(3):469-506

Shaw MN (2014) International law, 7th edn. Cambridge University Press, Cambridge

The Fund for Peace (2015) Fragile States index 2015: fragility in the world 2015. http://fsi.fundforpeace. org/rankings-2015. Accessed 13 Feb 2017

USAID (2013) Democracy, human rights and governance-assessment of Senegal: final report. http://pdf. usaid.gov/pdf_docs/pnaec828.pdf. Accessed 13 Feb 2017 